\title{
SPATIAL DISTRIBUTION OF ECONOMIC ACTIVITIES AND INTERNAL ECONOMIC INTEGRATION IN ROMANIA
}

\author{
Ihor YASKAL *, Liviu-George MAHA*, Oksana PETRASHCHAK \\ "Yuriy Fedkovych Chernivtsi National University, Ukraine \\ Alexandru Ioan Cuza University of lași, Romania
}

\begin{abstract}
This paper aims to consider two tendencies in economy simultaneously: internal integration within the country and localization of economic activities. Firstly, we examine the quantitative measurement of internal economic integration in Romania. Different methods of economic integration measuring have been developed over time, so we have defined and discussed three approaches. To estimate a level of internal integration the link between the region's share in the total output and production factors was estimated and the pattern of distribution of these shares among the regions of Romania was assessed. The calculations have underlined an increasing tendency to deepen the internal economic integration of the Romanian economy. Secondly, the analysis of spatial distribution of economic activity has demonstrated that the capital region Bucharest-llfov concentrates the biggest share of employment and production. This indicates that initially there were higher economic activities and a labor deficit has been created, which was later covered by moving employees from other regions. As a result, the capital region concentrates $14.35 \%$ of the civil economically active population and $26.78 \%$ of the regional gross domestic product in 2014. By computing the location coefficient, we have observed that the counties with the biggest shares in the total GDP are characterized by a higher level of specialization simultaneously in many sectors.
\end{abstract}

Key Words: production factor distribution, Kullback-Leibler divergence, internal economic integration, spatial distribution of economic activities, specialization, location quotient.

\section{Introduction}

The acceleration of globalization and geopolitical changes have recently given more attention to the role of market mechanisms in the allocation of resources within the economic landscape. Until the global financial crisis of 2008/09, the free market and globalization were associated with a relatively high level of economic growth and the expansion of the new middle class in the emerging economies, accompanied by a "new, complex and uneven geography of inequality" (Pike et al. 2016). Many thoughts have emerged recently that the era of globalization is fundamentally changing, even ending. To confirm this, data on world trade are given which is characterized by slow growth. Since 2010, world trade has grown only $2 \%$ annually, combined with the fact that the world-wide production of goods and services is growing by more than $3 \%$. This means that the ratio of trade to GDP is decreasing (Eichengreen 2016). Such trajectory indicates a revival of protectionism. Also, the globalization process enhances the importance of the location of economic activities. The changes in regional performance, associated with the last decades of globalization, have also altered the way in which we view the economic development of regions. This explains the research intensification of the spatial development of economic activity - economy of localization.

The growing attention to localization can be explained by the need to respond to the changes generated by the global economy, job losses and uneven distribution of consumer demand. In general, localization is interpreted as a process that changes global tendencies in the favor of a local one. At the same time, depending on the context, the term "local" predominantly means a 
part of the country, although in some cases it is associated with the country itself (sometimes even with a group of countries) (Hines 2000). In general, the localization policy is directed for increasing control over the economy by communities and regions. Increased community cohesion, reduction of poverty and inequality, greater access to livelihoods, better social infrastructure and environmental protection, and, consequently, the improvement of all aspects of security should be the result. The purpose of the localization process is to promote the emergence of a business owned by the local owners who use the local resources on a sustainability basis, who hire local employees with decent pay and serve mostly the local consumers (Shuman 1998). This means growing self-sufficiency in the local economy and a lower dependence on imports and the central government or institutions.

At the same time, in the process of transformations and reforms in the transition economy, the question of strengthening the interaction between regions as the main factor of sustainable economic growth attracts more and more attention according to the unanimous opinion of scientists and practitioners. The integrated development of the regions in the country can provide an increase in the efficiency of using the advantages of territorial labor division, realization of regional natural resource and scientific and production potential, and, therefore, contribute to the economic development of the country as a whole. The effectiveness of these processes depends directly on the coordinated interaction of market structures and the development of integration links at different territorial levels. Broadly defined, spatial interaction refers to a wide array of flows subject to various types of spatial frictions, such as traded goods, migrations, capital movements, interregional grants, remittances, and the interregional transmission of knowledge and the business cycle effects (Behrens and Thisse 2007). This is directly connected with the problem of economic security of the state and the processes of competitiveness formation. Therefore, the studying of the integration processes between regions within the country is extremely relevant today.

Globalization has also drawn attention to the often neglected role of space. It has made localities and their interactions more important for economic growth and prosperity (RodriguezPose 2011). The location (i.e. regions, the regional environment) becomes the epicenter of competitiveness. The region concentrates natural resources, human capital, scientific and industrial potential, it creates and strengthens competitive advantages which are the core of economic development and success.

Based on the mentioned above, we can talk about the relationship between the spatial distribution of economic activity and the integration between the regions of a particular country. In our opinion, interregional integration within the country intensifies the territorial division of labor and specialization, and the growth of specialization and, in turn, it strengthens the concentration of activities in certain places. And as a result of integration processes, cooperation intensifies, which enhances the development of integration processes. The tendency of economic activity to concentrate in space has always been an important topic for research both for economists and economic geographers. Awareness of what factors shape the economic landscape can better understand regional and national differences and the influence to these processes with the appropriately selected tools.

Many scientists investigate the integration processes and there is a wide literature devoted to economic localization. But in contrast to the existing research, this paper aims to consider two tendencies in economy simultaneously: the internal integration within the country and the localization of economic activities. The article is organized as follows. The next section contains a brief theoretical background of analyzed issues. After that we discuss the results gained from calculations and analysis and the last section concludes. 


\section{Methodology}

\section{Economic integration}

At a time when national borders are gradually eliminated, it is especially important to investigate the level of interactions between the regions of one country to enable the government to respond adequately to the changing economic environment. Otherwise, there are increasing threats of economic separatism and the disintegration of the state itself. Of course, the separatist tendencies lay more often in the political, cultural, linguistic and religious area, but the economic background is not completely excluded. This problem is typical for many countries. Ghosh examines the long-run growth performance and the regional divergence in per capita income across 15 major Indian states during the pre- and post-reform periods. The evidence shows that the divergence has increased in the post-reform period, mainly due to inter-state variations in the production structures, human capital and infrastructure (Ghosh 2008). Frey and Wieslhuber (2011) conducted an empirical analysis of the growth process on the regional level using the annual gross regional product (GRP) data for the period 1998-2008, on the 16 Kazakh regions and they stressed out that there was no evidence for regional convergence in Kazakhstan. Turganbayev (2016) explored regional convergence in Kazakhstan by income data and showed that incomes across the regions of Kazakhstan diverged over the whole period of 1993-2014 and the period of 1993-2006, and converged during the period of 2006-2014. After controlling for the rate of investment and population growth, it is evident that regional convergence occurred over the whole period of 1993-2014 (Turganbayev 2016).

This issue is investigated also in other countries: China (Herrmann-Pillath et al. 2014), Germany (Zuiddam 2016), Ukraine (Yaskal 2013) and ASEAN-members (Sethapramote 2015).

\section{Different methods of economic integration measuring}

Because a single indicator to measure economic integration does not exist, several techniques and instruments have been developed over time. We have indicated three main approaches. Approach \#1 (Bowen et al. 2010, 2011 Method). Authors derive three theoretical propositions regarding the distribution of output and the stocks of productive factors expected to arise among the members of a fully integrated economic area (IEA) in which goods and factors are freely mobile and policies are harmonized. The first proposition states that each member's share of the total area output will equal its share of the total area stock of each productive factor. Since this equal-share property applies to each IEA member, it does not directly address the important question of the distribution of output and factor shares across members. This question is addressed instead by the second theoretical proposition: the distribution of output and factor shares across IEA members will conform to a rank-share distribution that exhibits the Zipf's law. Zipf's law specifies a particular relationship among the member shares, namely, that the share of, for example, the output of the largest member is twice that of the second largest member; three times that of the third largest member, etc. The explanation for the emergence of Zipf's law for the distribution of member shares derives from the expected randomness of these shares when policies are fully harmonized across area members. The third theoretical proposition is that, given the Zipf's law, the long-run distribution of output and factors across area members is unique and it depends only on the number of IEA members. This latter result is significant, since it means that the relative position of each IEA member only depends on the total number of members. This methodology was proposed by Bowen et al. $(2010,2011)$. They assess the level of economic integration between the U.S. states and EU members, based on Regional Trade Agreements. Noteworthy, this approach is used for estimating the level of integration within a country (i.e. USA), and between countries within a particular group (i.e. EU, NAFTA, etc.).

Approach \#2. It is based on the most general measure of integration, concentrating on 
spillovers in economic growth: if a geographical area is integrated economically, there should be spatial interdependencies between the levels of economic growth in the different regions. This co-movement can be caused not only by market forces, but also by other forms of linkages, established, for example, through large-scale government projects or centralized redistribution. This method was used by Herrmann-Pillath et al. (2014). Their objective is to understand how growth rates in Chinese prefectures are correlated across and within provincial and cultural borders. For this purpose, they look specifically at neighbouring prefectures, that is, prefectures with common borders. The idea is that, if economy is integrated, neighbors should exhibit particularly strong links to each other and thus exhibit stronger co-movement of growth rates, as opposed to prefectures distant from each other. If administrative or cultural differences create obstacles for the emergence of economic ties, these links should be absent and the co-movement of growth among neighbouring prefectures should be the same as among a random pair of distant prefectures. To identify the effect, two main approaches are used: regressions for dyads of prefectures and spatial econometrics.

As for the authors, the using of this methodology is driven by two considerations. First, it is the data availability. A possible alternative to studying intra-provincial integration if prefectural data are available would be to estimate provincial border effects from the gravity equations; yet the data on the inter-prefectural trade is not available (this is not a deficit of Chinese data: in many countries in the world, because there are no internal customs controlling goods and factor flows, there are no reliable statistics on the inter-regional trade). Furthermore, the border effect in gravity equations shows just that there is some disruption of trade and factor flows at the border, but it does not allow any clear statement regarding the significance of the intraprovincial integration in terms of its economic effect on the performance of the local economies. Second, an advantage of the measures we use is that it does not rely on particular channels of economic integration (i.e. trade or migration). There are different channels through which spillovers can happen, among others, linkages via trade and investment, imitation of technologies and knowledge diffusion, migration, or demand pull.

Approach \#3. A number of papers investigate the correlation of growth rates and the coincidence of business cycles as a measure of economic integration and on spatial spillovers (Xu 2002, Xu and Voon 2003, Ying 2003, Sandberg 2004, Golley and Groenewold 2007, Poncet and Barthélemy 2008, Huang et al. 2015).

Sure, this list is not completed. There are several other methods and indicators of economic integration. But they combine the existing models. For example, Storonyanska (2009) used some parameters based models of convergence and got important conclusions after the factor analysis. At the same time, Yevdokymenko and Yaskal (2012) proposed a method for detecting the approximate directions of interregional production and resource integration in industry and the manufacturing industry using the Euclidean distance, the fuzzy clustering and the gravity model.

Zuiddam (2016) gives a short description of three groups of measurement indicators: institutionbased indicators, outcome-based indicators, and factor-based indicators. Most popular measures are outcome-based indicators and they are some sort of cross-country flow variable. Institutionbased indicators reflect the level of institutional convergence or the policy harmonization across countries. Therefore, the institutional convergence alone is an incomplete indicator. Outcomebased indicators are the most common methods for measuring the economic integration between countries. These indicators combine foreign trade or investment flows between countries with gravity equations to evaluate these flows. One particular popular factor-based is the income convergence. The mechanism behind income convergence through economic integration is the equation of the marginal products of labor, when production factors are completely mobile. 


\section{Evaluation of localization review}

There are a wide range of methodological frameworks and techniques for the evaluation of localization. The measures developed are either in the form of indexes (Ellison and Glaeser 1997, Maurel and Sédillot 1999, Devereux et al. 2004, Mori et al. 2005) or in the form of numerical methods (Feser and Sweeney 2002, Duranton and Overman 2005, Marcon and Puech 2010). A more detailed review of the methodological contributions to the accurate measurement of localization is presented in Fratesi (2008), Strotebeck (2010), Billings and Johnson (2016).

In order to evaluate the spatial concentration of each economic activity, we compute the location quotient (LQ) for regions. Of course, this indicator has a number of shortcomings, as it was indicated by Fratesi 2008, but despite this, it still remains one of the most popular (Liao 2012, Mota and Brandão 2013, Morrissey 2016).

In this paper, we have employed the Bowen et al. 2010, 2011 method, in order to examine the quantitative measurement of the internal economic integration in Romania. Most papers limit their attention to NUTS 2 level data (development regions and macro regions). However, the highly aggregate nature of statistics at macro regional level masks important tendencies in regional integration. Nevertheless, this literature has paid very limited attention to the intercounties (NUTS 3 ) links. This paper tries to fill this gap.

The chapter is organized as follows. Section one offers a short theoretical explanation of distribution of output, labor and capital across the integrated economic space (within a country) and it discusses the data used for estimating the factor and output distribution among Romanian regions. Section two presents the empirical results of the economic integration evaluation and the spatial distribution of economic activities. The third section summarizes the main findings.

\section{Theoretical background and data}

Bowen et al. $(2010,2011)$ consider the distribution of output and production factors among the members of an integrated economic space (IES), in which goods and factors of production (resources) are mobile and policies are harmonized. Thus, as an IES, we shall consider the national economy of Romania (set of regional economies), and by the members of the IES - the Romanian regions. The theoretical background for the distribution of the output and factors of production among regions - equal-share relationship and rank-share distributions and Zipf's law - are characterized and described in detail in Bowen et al. $(2010,2011)$.

We have started from the assumption that the long-term distribution of shares among the regions of the integrated economic space exhibits the Zipf's law. This means that the theoretical share value of each region could be calculated on the basis of the number of members. In our case, we used three groups of regions: macro regions, development regions and counties. The theoretical share values for the regions of Romania are given in Table 1.

For the Romanian regions, the output was measured by the gross domestic product (GDP) by corresponding regions. The development regions correspond to the NUTS 2 level divisions in the European Union. The factor "labor" for each macro region, development region and county was measured by the number of civil economically active population which characterizes the potential labor force and employment population rate, consisting of the civil employed population and the registered unemployed ${ }^{1)}$.

1) Data on civil economically active population by regions are available at: http://statistici.insse.ro/shop/index.jsp?page=tempo3\&lang=en\&ind=FOM102A 
Table 1

Theoretical share values assuming that the distribution of share exhibits the Zipf's Law

\begin{tabular}{|l|c|}
\hline \multicolumn{1}{|c|}{ Group of regions } & Theoretical share values (descending) \\
\hline $\begin{array}{l}\text { 4 macroregions (NUTS } \\
\text { 2) }\end{array}$ & $0.4800 ; 0.2400 ; 0.1600 ; 0.1200$ \\
\hline 8 development regions & $0.3679 ; 0.1840 ; 0.1226 ; 0.0920 ; 0.0736 ; 0.0613 ; 0.0526 ; 0.0460$ \\
\hline (NUTS 2) & \\
\hline & $0.2311 ; 0.1156 ; 0.0770 ; 0.0578 ; 0.0462 ; 0.0385 ; 0.0330 ; 0.0289 ;$ \\
& $0.0257 ; 0.0231 ; 0.0210 ; 0.0193 ; 0.0178 ; 0.0165 ; 0.0154 ; 0.0144 ;$ \\
& $0.0136 ; 0.0128 ; 0.0122 ; 0.0116 ; 0.0110 ; 0.0105 ; 0.0100 ; 0.0096 ;$ \\
& $0.0092 ; 0.0089 ; 0.0086 ; 0.0083 ; 0.0080 ; 0.0077 ; 0.0075 ; 0.0072 ;$ \\
\hline & $0.0070 ; 0.0068 ; 0.0066 ; 0.0064 ; 0.0062 ; 0.0061 ; 0.0059 ; 0.0058 ;$ \\
\hline
\end{tabular}

Source: own calculations

The estimation of a county's physical capital stock faces some difficulties. There is no statistical data regarding the tangible assets and investments by counties in Romania. However, every enterprise possesses some amount of fixed capital. Assuming more of the enterprises in the county means a greater amount of fixed capital. So, if we operate with shares of counties and their ranks, not with numbers itself, we have decided to use the number of enterprises by counties instead of the physical capital. We can suppose that a county's share of enterprises in total partly reflects the share of the physic capital of this county in total. And a difference in the number of enterprises between counties reflects the differences in stock of the physical capital ${ }^{2}$. The procedure used by Munnell (1990), Garofalo and Yamarik (2002), as well as Bowen et al. (2010, 2011), does not offer appropriate results for the Romanian regions.

\section{Results and Discussion}

\section{The equal-share relationship}

We will further verify the validity of the equal-share relationship hypothesis by analyzing the "weak" form of this relationship, namely whether that there is conformity (pair-wise) between the rankings of the output and the factor shares across regions in Romania, as Yaskal (2013) did for Ukraine.

Table 2 offers data for the Spearman rank correlation coefficient calculus for the pair-wise rankings of shares for each county between 1995 and 2015. The fairly high correlation confirms the consistent distribution between the pair-wise ranks. The correlation coefficients are in some cases close to 1, which proves an almost perfect monotonic relationship between the GRP and the capital shares. The rank correlation with the human capital is generally lower and it is demonstrating a weaker confirmation of the relationship of equal shares. Except for some differences between counties (population, area, resources etc.), this result may indicate the smaller "contribution" of human capital in the GRP of Romanian regions compared to the "contribution" of capital. At the same time, we can mention the existence of a lower correlation with the share of human capital, which can be caused by a lower mobility of this factor, comparing to the capital.

2) Data on number of enterprises by regions are available at: http://statistici.insse.ro/shop/index.jsp?page=tempo3\&lang=en\&ind=INT1010 
Spearman rank correlations between share values*

Table 2

\begin{tabular}{|c|c|c|c|}
\hline Year & $\begin{array}{c}\text { Output-Physical } \\
\text { capital }\end{array}$ & $\begin{array}{c}\text { Output-Human } \\
\text { capital }\end{array}$ & $\begin{array}{c}\text { Physical capital-Human } \\
\text { capital }\end{array}$ \\
\hline $\mathbf{1 9 9 5}$ & - & 0.937 & - \\
\hline $\mathbf{1 9 9 6}$ & - & 0.925 & - \\
\hline $\mathbf{1 9 9 7}$ & 0.930 & 0.934 & 0.895 \\
\hline $\mathbf{1 9 9 8}$ & 0.921 & 0.901 & 0.886 \\
\hline $\mathbf{1 9 9 9}$ & 0.925 & 0.879 & 0.873 \\
\hline $\mathbf{2 0 0 0}$ & 0.930 & 0.881 & 0.874 \\
\hline $\mathbf{2 0 0 1}$ & 0.927 & 0.896 & 0.892 \\
\hline $\mathbf{2 0 0 2}$ & 0.947 & 0.917 & 0.904 \\
\hline $\mathbf{2 0 0 3}$ & 0.939 & 0.912 & 0.894 \\
\hline $\mathbf{2 0 0 4}$ & 0.952 & 0.922 & 0.905 \\
\hline $\mathbf{2 0 0 5}$ & 0.950 & 0.911 & 0.900 \\
\hline $\mathbf{2 0 0 6}$ & 0.944 & 0.910 & 0.914 \\
\hline $\mathbf{2 0 0 7}$ & 0.951 & 0.917 & 0.915 \\
\hline $\mathbf{2 0 0 8}$ & 0.955 & 0.933 & 0.922 \\
\hline $\mathbf{2 0 0 9}$ & 0.955 & 0.922 & 0.914 \\
\hline $\mathbf{2 0 1 0}$ & 0.954 & 0.911 & 0.910 \\
\hline $\mathbf{2 0 1 1}$ & 0.952 & 0.905 & 0.909 \\
\hline $\mathbf{2 0 1 2}$ & 0.951 & 0.909 & 0.907 \\
\hline $\mathbf{2 0 1 3}$ & 0.953 & 0.924 & 0.916 \\
\hline $\mathbf{2 0 1 4}$ & 0.962 & 0.932 & 0.917 \\
\hline $\mathbf{2 0 1 5}$ & - & - & 0.920 \\
\hline${ }^{*}$ Correlation coefficients are significant from the null-hypothesis at the level 0.01. \\
\hline "-": data are not available & & \\
\hline Source: own calculations & \multicolumn{2}{|c|}{} \\
\hline
\end{tabular}

There is an evident general increasing tendency for all Spearmen correlation coefficients within the analyzed period. This means that the proportion of the investigated regions is characterized by smaller differences. These results confirm the "weaker" form of the equal-share relationship. The increase of the correlation coefficients may indicate that the equalization of marginal returns between regions becomes more perfect.

\section{Spatial distribution of economic activity}

The Appendix (tables from A1 to A4) describes the evolution of output and employment shares distribution and their rankings for the NUTS 3 and NUTS 2 Romanian regions. In particular, Tables A1 and A2 show the ranking and output share value for the 42 counties and 8 development regions in 1995, 2001, 2006, 2010 and 2014, along with the changes in rank and share values between these years. Tables A3 and A4 show the ranking and employment share value for the similar regions and years.

Table A1 shows that Bucharest has constantly increased its share of production during 19952010. This share has increased by $10.61 \%$ between 1995 and 2014. Besides Bucharest, the shares of Ilfov (1.05), Cluj (0.97), Constanta (0.93), Timis (0.92) and Prahova (0.61) have increased the most. If Cluj, Constanta, Prahova and Timis counties were earlier among the leaders in terms of output, Ilfov made an abrupt "jump" in the ranking (+21) due to its location near the capital city. The growth of county-leader's shares of the regional GDP occurred by 
reducing the shares of 30 (1995-2001), 21 (2001-2006), 29 (2006-2010) and 31 counties (2010 $-2014)$. Among the counties that have significantly reduced their position in the ranking are Vrancea (-10), Neamt (-8), Galati (-6) and lalomita (-7), Teleorman (-6). At the same time, there was also a reduction of the share output of these counties: Vrancea $(-0.78)$, Neamt $(-0.9)$, Galati (-1.18), lalomita (-0.72), Teleorman (-0.71).

Table A2 also shows a steady increase of the capital region: the output share of Bucharest-Ilfov increased by 11.67 and this is only one positive change for the analyzed period. The other development regions decreased their shares of production. It is interesting that during 2010 2014 , the shares of the four regions have increased, but during the whole period (1995-2014) only one maintained the ascending path.

If we consider the distribution of employment ranking and shares (Tables A3 and A4), the leading positions are occupied by the same counties, plus Bihor. The growth of the countyleaders by employment was due to the reduction of the shares of 19 counties between 1995 and 2001, 32 counties between 2001 and 2006, 27 counties between 2006 and 2010 and 26 counties between 2010 and 2014. The counties which reduced their position in the ranking were Galati (rank: -6; share value: -0.65), Hunedoara (rank: -6; share value: -0.6), Gorj (rank: 6; share value: -0.38). For example, Hunedoara and Gorj lost some important economic activities, being specialized in mining, and it became the main reason of such reduction. Table 4 shows a much more uniform distribution of employment shares between regions, but also one can see a growth of concentration of employment in the Bucharest-llfov region. The dramatic growth of the capital region's share occurred during the 2001-2006 period, while the production share had increased before, namely between 1995 and 2001. This indicates that initially there were higher economic activities and a labor deficit has been created, which was later covered by the moving employees from other regions (for the same period, 32 counties decreased their share, and only 10 increased it). Another reason of huge concentration of economic activities in the Romanian capital is that the public sector in this country is important and almost all government agencies are located in the capital city. So, it is more appropriate to run business in the capital. As a result, the capital region concentrates $14.35 \%$ of the civil economically active population and $26.78 \%$ of the regional gross domestic product in 2014 .

We can note that the trend towards the concentration of economic activity in the capital is a common feature for the transition countries (and not only). According to Eurostat, in a majority of the multi-regional EU Member States, capital city regions were generally those with the highest average GDP per capita; the only exceptions to this rule were Germany, Italy and the Netherlands. The capital city regions of Bulgaria, the Czech Republic, Denmark, Ireland, France, Croatia, Portugal, Slovenia, Slovakia and Sweden were the only regions from each of these EU Member States where GDP per capita was higher than the national average in 2014 Also, Romania is characterized by considerable differences in the levels of GDP per capita between the regions of the same country (with the United Kingdom, France and Slovakia) (Eurostat 2016).

The capital agglomeration grows significantly faster than the other regions. One can assume that the capital in a transition economy plays the role of "region-gate" through which the country gets new knowledge, technologies and investments. Bucharest-llfov is the most development region, with a labor force predominantly specialized in services and constructions, the highest employment rate and a significant contribution of the younger and higher educated persons (Dachin and Popa 2011). This is a positive effect from the growth of capital. The negative side is the abrupt growth of the capital region, which causes the deepening of regional disparities (Antonescu 2012).

It is worth noting the growth of regional disparities within the development regions. The Western region takes the $7^{\text {th }}$ position by the output share during the study period (Table A2). At 
the same time, the counties' shares which are included in this region vary in opposite directions. Only Timis increased by 0.92 (rank -1), but other counties reduced their share: Caras-Severin by 0.24 (rank +6 ), Arad by 0.13 (rank +3 ) and Hunedoara by 0.65 (rank -5$)$. The same trajectory is observed in the South-Muntenia region: Prahova increased by 0.61 (rank -1) and Giurgiu by 0.01 (rank +6 ), while other counties reduced their share: Arges by 0.55 (rank did not change), Dambovita by 0.44 (rank did not change), Teleorman by 0.71 (rank -6), lalomita by 0.72 (rank -7) and Calarasi by 0.41 (rank -3). The South-Muntenia region takes the $2^{\text {nd }}$ position during the analyzed period (Table A2).

Tables A1 to A4 allow making some considerations about the direction of spatial distribution of economic activity in Romania. The data indicate the growth of output and employment shares of the capital and the counties from the Western and Central regions. In return, counties from Eastern regions (North-East and South-East) have decreased their share values. Constanta is the exception because its employment share value has increased over the period. This county has a competitive advantage due to the main Romanian seaport which is located here. The situation of Constanta proves the correctness of McCord and Sachs's argumentation (2013: 6): "an economy's physical access to sea-based ports is crucial for economic development".

These trends allow ascertain about evidence of forming clear leading counties within the Romanian development regions. This conclusion can be confirmed by the share of the county in the regional gross product of the region (Table 3).

Table 3 shows that there are a few counties in each development region with a GDP share much larger than others. Moreover, each region has several leaders, except of the capital region. The capital is the indisputable leader, as it was emphasized in the separate development region. Noteworthy trends are being observed in the changing of shares. Counties-leaders' share in each development region are changing in different directions. For example, in the Nord-Western region, the share of Cluj has increased, but Bihor's share has decreased; in the Centre region the shares of Brasov and Sibiu have increased, but the share of Mures has decreased etc. The South-Western Oltenia is the exception because both leaders' shares have increased.

This means that the economic activity in the first, second and fourth macro regions grows slower (the macro region's GDP share value in total GDP has decreased from $24.2 \%$ in 1995 to $22.4 \%$ in 2014 , for the first; from $26.8 \%$ in 1995 to $21.3 \%$ in 2014 , for the second, and from $18.4 \%$ in 1995 to $16.4 \%$ in 2014 , for the fourth). At the same time, the GDP share value of macro region 3 (including the capital) has increased from 30.3\% (1995) to 39.8 (2014).

In order to confirm these tendencies, we have grouped the counties with the biggest share, and we have calculated their regional product and some ratios (Fig. 1). The lalomita and Calarasi counties were included in the Eastern group due to their geographical proximity to the South-East development region.

Figure 1 shows that the Western and Central counties' GDP has increased faster than the Eastern one. The growing role of the regional economy in Western and Central districts is shown from the ratios between the corresponding groups. In 1995, the Eastern and Western groups' GDP was almost equal, but in 2007 the ratio was 1.44 . Moreover, after this year this disparity has been decreased. So, the economy of Western Romania makes a greater impact on the national economy than the Eastern part of the country. We can see the same situation with WesternCentral / Eastern Ratio which increased even faster. This phenomenon was predicted by Resmini (2003), who tried to understand what type of regions would gain and what type of regions would lose from the EU enlargement processes. She claimed that "proximity to the EU has stimulated a catching up process which has contributed to overcome the disadvantage of being located in a peripheral position with respect to capital cities" (Resmini 2003: 219). 
Ihor YASKAL, Liviu-George MAHA, Oksana PETRASHCHAK

Counties with the biggest GDP shares

Table 3

\begin{tabular}{|c|c|c|c|c|c|c|c|c|c|c|c|c|}
\hline \multirow{2}{*}{$\begin{array}{l}\text { Develop- } \\
\text { ment re- } \\
\text { gion }\end{array}$} & \multirow{2}{*}{$\begin{array}{l}\text { County- } \\
\text { leader (s) }\end{array}$} & \multicolumn{11}{|c|}{ Share in development region's GDP, $\%$} \\
\hline & & 1995 & 2000 & 2004 & 2006 & 2007 & 2008 & 2010 & 2011 & 2012 & 2013 & 2014 \\
\hline \multirow{2}{*}{ North-West } & Cluj & 29.3 & 33.3 & 33.1 & 33.5 & 35.8 & 35.2 & 36 & 37.4 & 38.1 & 38.7 & 38.9 \\
\hline & Bithor & 23.6 & 23.2 & 24.3 & 24 & 23.1 & 22.7 & 22.3 & 20.8 & 19.5 & 19.5 & 19.9 \\
\hline \multirow{3}{*}{ Center } & Brasov & 27.5 & 27.9 & 27.3 & 27.4 & 28.2 & 28.3 & 30.1 & 29.6 & 29.9 & 30.1 & 30.1 \\
\hline & Mures & 21.5 & 21.8 & 21.7 & 20.7 & 19.5 & 19.5 & $\overline{18.4}$ & 18.5 & 19.5 & 19.3 & 19.7 \\
\hline & Sibiu & 16 & 16.7 & 18 & 19.4 & 18.9 & 19.8 & 19.6 & 19.7 & 19.5 & $\overline{19.4}$ & 19 \\
\hline \multirow{2}{*}{ North-East } & Tasi & 24.3 & 25.6 & 25.4 & 26.4 & 27 & 27.6 & 29 & 28.9 & 28.6 & 30.1 & 30.7 \\
\hline & Bacau & $\overline{22.4}$ & 22 & 22.8 & 22.1 & 21.4 & 21.8 & 21.7 & 20.5 & 20.5 & 19.1 & $\overline{19.1}$ \\
\hline \multirow{2}{*}{ South-East } & Constanta & 31.3 & 36.5 & 35.6 & 38.4 & 36.7 & 35.7 & 37.4 & 37.3 & 41.2 & 42.8 & 45.1 \\
\hline & Galati & 23.2 & 20.6 & 20.3 & 18.5 & 19.2 & 19.6 & 19.5 & 19.1 & 17.5 & 17 & 16.8 \\
\hline \multirow{2}{*}{$\begin{array}{l}\text { South- } \\
\text { Muntenia }\end{array}$} & Prahova & 28.1 & 30.2 & 28.2 & 30.8 & 30.6 & 30.6 & 27.6 & 29.8 & 30.2 & 33.6 & 37.6 \\
\hline & Arges & 21.2 & 23.4 & 24.8 & 27.1 & 26.9 & 26.1 & 25 & 23.9 & 22.2 & 21.7 & 20.6 \\
\hline $\begin{array}{l}\text { Bucharest- } \\
\text { |lfov }\end{array}$ & Bucharest & 90 & 92.6 & 90.1 & 89.1 & 90.2 & 90.4 & 90.5 & 90.4 & 88.8 & 90 & 90.4 \\
\hline \multirow{2}{*}{$\begin{array}{l}\text { South-West } \\
\text { Oltenia }\end{array}$} & Dolj & 28.8 & 28.9 & 30.6 & 31 & 31.3 & 33.3 & 32.1 & 32.1 & 32.1 & 32.6 & 34.3 \\
\hline & Gorj & 19.2 & 21.2 & 21.3 & 21 & 21.8 & 20 & 23 & 23 & 22.7 & 22.6 & 20.6 \\
\hline \multirow{2}{*}{ West } & Timis & 38.1 & 39.2 & 40.7 & 43.8 & 44.1 & 47.7 & 48.3 & 49 & 46.5 & 49 & 48.5 \\
\hline & Arad & 23.7 & 24.6 & 24.2 & 23.6 & 22.2 & 21.5 & 21.7 & 22.3 & 22.4 & 22.7 & 22.5 \\
\hline
\end{tabular}

Source: own calculations based on data from the National Institute of Statistics

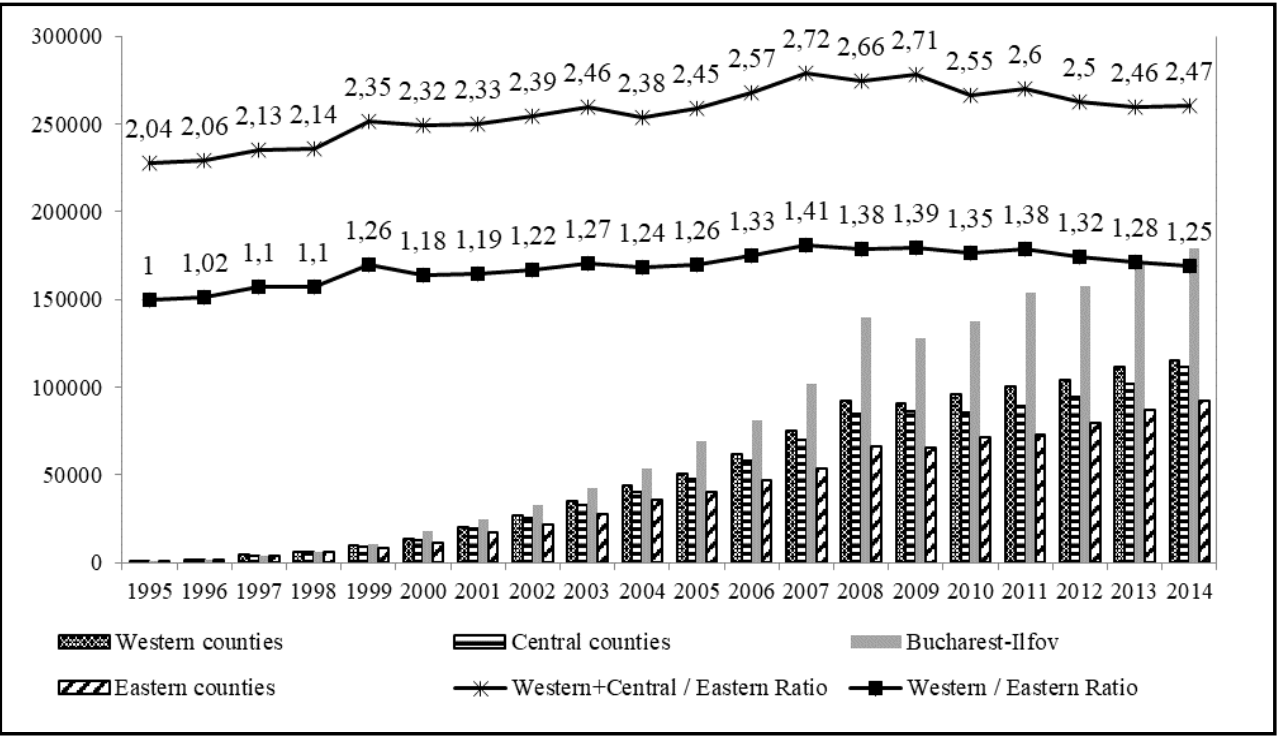

Fig. 1 - Regional GDP of different groups of counties

Source: own calculations based on data from National Institute of Statistics

The previous material can be summarized as follows. The economic activity in Romania has a clear tendency to concentrate in several leading counties. They attract production factors from other counties, so leaders' share increases and other counties' share reduces in the meantime. The proof of this statement is that the number of districts which have increased their share in the total GDP and employment is smaller than the number of districts which have reduced their share. This concentration leads to the fact that some counties are growing at the expense of others, thereby increasing regional disparities. In addition, the economic activity "shifts" from East to the West (Cluj, 
Timis, Arad, Dolj, Gorj), the Centre (Brasov, Sibiu) and the capital region (Bucharest-llfov). Among the Eastern counties, only Constanta and lasi occupy a dominant position.

\section{Measures of internal economic integration}

For estimating the level of economic integration between the Romanian regions, we further need an index for measuring the distance between the distribution of the actual and theoretical specific weights. Since the Kullback-Leibler divergence (KLD) is used to measure the difference between two probability distributions (Kullback and Leibler 1951), we can similarly use KLD to measure the distance between the actual and the theoretical share distributions:

$$
K L D\left(\bar{S}: S_{t}\right)=\frac{1}{3} \sum_{j=Y, K, L}\left(\sum_{m=1}^{M} \bar{S}_{m j} \ln \left(\frac{\bar{S}_{m j}}{S_{m j t}}\right)\right)
$$

where $S_{m j t}$ - observed proportion at the time, and ${ }^{t} ; \bar{S}_{m j}$-independent of time the theoretical part.

The values of KLD range between zero and infinity. It is equal to zero (which is interpreted as the full integration) when the proportions are pair-wise equal, i.e. $\bar{S}_{m j}=S_{m j t}$ as of the date $t$ and for all $m$ and ${ }^{j}$. Otherwise, the detected deviations indicate how far the group of investigated regions is from the complete integration. According to Bowen et al. (2010: 403), the formalization of equation (1) has one drawback: "...it is not symmetric, in the sense that a deviation between an actual and theoretical share can be negative or positive". Therefore, you cannot tell if a zero value of KLD arise due to equidistant shares around a common mean or due to a zero distance between shares. Thus, as in Bowen et al. (2010), the symmetrical version of Kullback-Leibler divergence (SKLD) is preferred:

$$
\operatorname{SKLD}\left(\bar{S}: S_{t}\right)=\frac{1}{3} \sum_{j=Y, K, L}\left(\sum_{m=1}^{M}\left(\bar{S}_{m j}-S_{m j t}\right) \ln \left(\frac{\bar{S}_{m j}}{S_{m j t}}\right)\right)
$$

The SKLD values are usually higher for the respective KLD, since all deviations between the actual and the theoretical shares in the index SKLD are positive (Bowen et al. 2010). Since the parameters (1) and (2) show the extent of divergence, we consider appropriate to calculate the inverse indicators to obtain the integration level, the inverse of the KLD and SKLD being marked as I - KLD and I-SKLD respectively. To better compare the dynamics and the level of integration between the different types of regions for the period, we have graphically represented the value of the I-SKLD in Figure 2.

The results show that the level of economic integration between the regions in Romania has gradually increased since 1997, despite some changes in the direction of reduction. The deterioration of the economic environment in 2009-2010 obviously led to unequal changes in the specific weights of output and production factors of the regions in total, and thus they increased the discrepancy between the theoretical and the actual distribution of shares. 


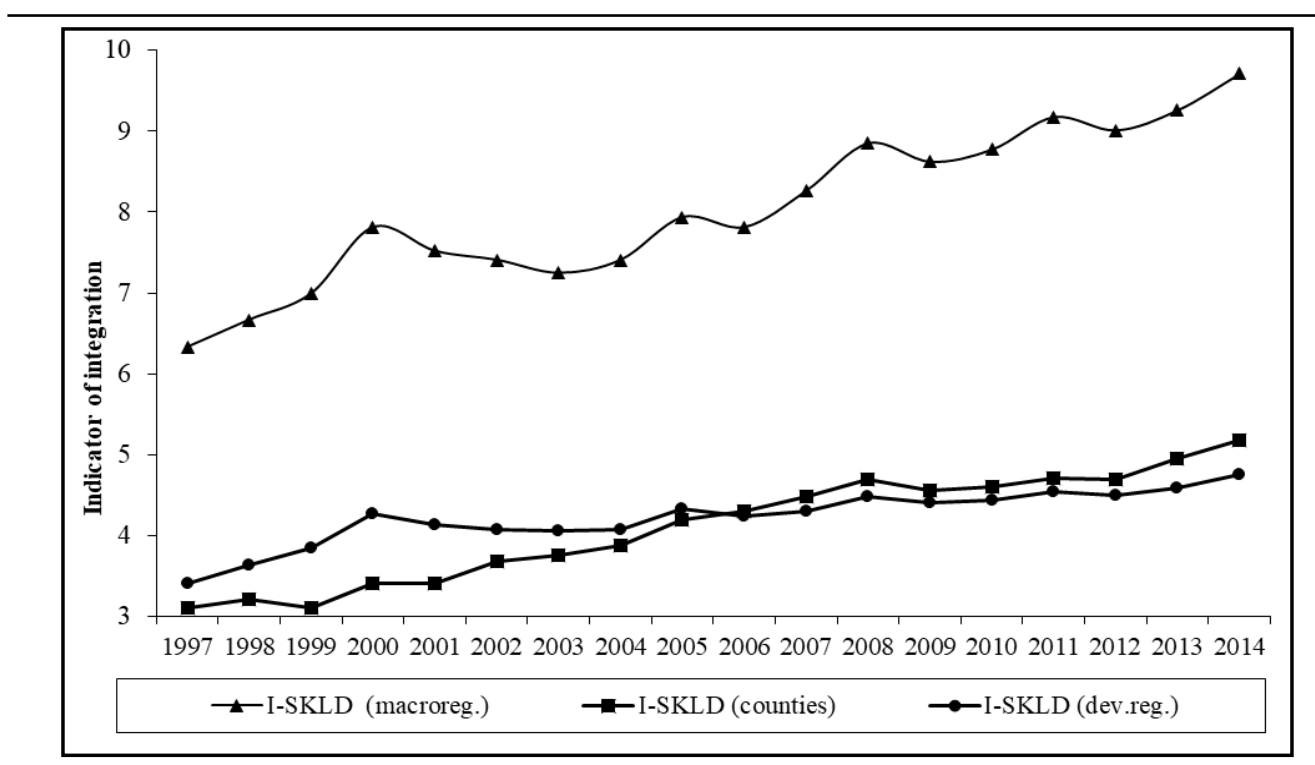

Fig. 2 - Level of interregional integration in Romania Source: own calculations

We have obtained interesting results regarding the level of integration between the NUTS 3 regions. From the start of the period, the differences between the indicators of integration for the counties and the development regions were higher, but, from 2000, they have decreased. During 2004-2012, the level of integration for the counties and the development regions was almost the same. And then, the differences also became higher. This finding means that the development regions in Romania respect correct economic tendencies. So, a big difference between I-SKLD for NUTS 2 and NUTS 3 shows that carrying out regional research only for macro regions is not enough. It is necessary to pay attention to the lower level of regions in order to avoid the impact of aggregation data.

\section{Internal integration and localization of economic activities}

From Tables A1-A4, we can see that only a few counties' shares are growing constantly, while the share of the absolute majority reduced. We have compared the share of county-leaders (Table 3) with the level of specialization of these counties. In order to evaluate the spatial specialization of each sector by NUTS 3 , we computed the location coefficient. The location quotient (LQ) is the most commonly used measure of specialization (Billings and Johnson 2012). The conventional LQ is a measure of an industry's presence in a particular location compared to the general spatial distribution of the economic activity. For a given industry, the $L Q$ is calculated as the ratio of its share of total employment in a sub-region relative to that industry's share of total employment in the broader region. The results of the calculations are presented in Table 4 (2008) and Table 5 (2014). The coefficients greater than one are bold selected, and this indicates the specialization of the region in a particular sector.

Based on the data from Tables 4 and 5, we observe that the counties with the biggest shares in the total GDP are characterized by a higher level of specialization simultaneously in many sectors. For instance, Constanta (the share increased from 3.68 in 2008 to 5.07 in 2014) has a strong level of specialization in such sectors: Electricity, gas, steam and air conditioning production and supply; Water supply; sewerage, waste management and decontamination 
activities; Construction; Transport and storage; Hotels and restaurants. At the same time, Timis concentrates a higher level of employment in the sectors: Manufacturing; Information and communication; Real estate activities; Other activities of the national economy. One needs to pay attention to the capital, Bucharest, which concentrates nearly a quarter of the total national GDP.

Tables 4 and 5 show the increase of the capital position, Bucharest, which has the biggest GRP share and is the clear leader of ranking during the analyzed period. The capital metropolis specializes almost in all sectors, except Agriculture, forestry and fishing and Industry. That means a high level of diversification of the city economy. The location quotients with a value greater than 2 indicate that Bucharest concentrates almost all the activity in these sectors: Information and communication; Financial intermediation and insurance; Professional, scientific and technical activities; Activities of administrative services and of support services; Shows, culture and recreation activities. In this case, it is possible to use further methods for determining the future dynamics of the economic activities (Vyklyuk et al. 2016).

In 2014, compared with 2008, there are the following trends. In 2008, Bucharest had the highest coefficients of localization (more than 3 ) in such areas as: Information and communication (4.36); Financial intermediation and insurance (3.2); Shows, culture and recreation activities (3.54); Activities of administrative services and of support services (3.01). The level of localization has significantly decreased in three areas from the four mentioned above: Information and communication (3.36); Financial Shows, culture and recreation activities (2.01); Activities of administrative services and of support services (2.5). At the same time, the coefficients of localization in some counties increased. This fact may be an indication of the economic activities diversification in the regions as well as an evidence of the establishment of other business centers in the country, specialized in certain types of economic activity. However, the capital city has not lost its position in the share of GDP, even though some regions have also increased. This was due to a slight increase in the coefficients of localization by other types of economic activity. The domination of the capital is peculiar not only for Romania but also for other post-Soviet countries. This is explained by the fact that the capital city is the largest city in the country and it represents the national industrial, scientific and cultural center. It also attracts the localization of central offices of large companies. Another reason is that most companies registered in Bucharest have subsidiaries in the other regions, and they report and pay taxes at the place of registration, i.e. in the capital city.

Also we point out that the sector 'Agriculture, forestry and fishing' has almost the same localization level in both years compared, while the sector 'Industry' is characterized by essential changes. Industry became more localized in: Bihor, Brasov, Arges, Timis and Arad (Manufacturing); Mures, Sibiu and Gorj (Mining and quarrying). The last one has huge LQ values in the areas: 'Mining and quarrying' (12.23), 'Electricity, gas, steam and air conditioning production and supply' (5.12) and 'Water supply; sewerage, waste management and decontamination activities' (1.35), in 2014. Counties which are specialized in Construction are the same although the value of the localization quotient has changed.

The sector 'Wholesale and retail; repair of motor vehicles and motorcycles' has also become more concentrated in 2014 (6 counties) than in 2008 (9 counties). It means that large entities are more common in this type of business and more efficient. And such structures, as usual, are located in particular places. As we can see, the number of these places has declined.

Some changes have occurred also in the localization of service activities. For instance, 'Information and communication', in 2008, was very localized: it was located in Bucharest ( $L Q=4,36)$, Timis ( $L Q$ $=1,81)$ and Cluj $(L Q=1,13)$ only. During the analyzed period, this activity disseminated from certain centers to other counties: Brasov $(L Q=1,27)$ and lasi $(L Q=1,11)$, in 2014. We think that the main 
Counties and their LQ in 2008

Source: own calculations

\begin{tabular}{|c|c|c|c|c|c|c|c|c|c|c|c|c|c|c|c|c|}
\hline 言高辞 & 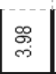 & $\stackrel{5}{\sim}$ & $\underset{m}{\frac{5}{m}}$ & $\frac{O}{\mathrm{~N}}$ & $\frac{9}{i}$ & $\tilde{\sim}$ & $\bar{m}$ & 渠 & జ̃ & $\stackrel{\substack{\infty \\
\infty}}{\infty}$ & $\approx$ & $\overline{\mathrm{A}}$ & 总 & 总 & 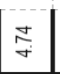 & \\
\hline 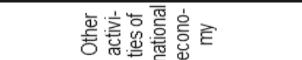 & $\cong$ & F & 营 & $\stackrel{9}{i}$ & 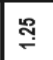 & 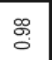 & $\underset{+}{+}$ & 疍 & $\stackrel{\circ}{\circ}$ & $\frac{0}{5}$ & \begin{tabular}{|l|l|}
9 \\
0 \\
0
\end{tabular} & $\stackrel{\infty}{\check{\infty}}$ & 8 & : & $\stackrel{9}{9}$ & \\
\hline 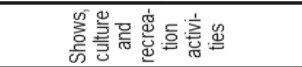 & உ & F & $\begin{array}{l}0 \\
0 \\
0\end{array}$ & ذ్丶 & : & \begin{tabular}{|l|l|}
8 \\
\end{tabular} & 宓 & 9 & $\bar{\Xi}$ & 8 & 苔 & 营 & $\begin{array}{l} \\
\end{array}$ & 웅 & : & 4 \\
\hline 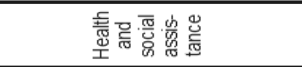 & | & $\stackrel{2}{\circ}$ & 8 & 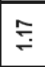 & 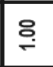 & $\stackrel{9}{q}$ & $\stackrel{?}{\div}$ & 要 & s. & 홍 & 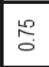 & $\stackrel{0}{\stackrel{0}{\circ}}$ & 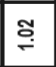 & 8 & $\stackrel{9}{\circ}$ & \\
\hline 政 & Фุ & $\stackrel{8}{-}$ & $\cong$ & 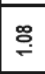 & $\stackrel{8}{:}$ & $\underset{+}{Z}$ & $\stackrel{\infty}{=}$ & 䓵 & $\stackrel{\square}{\square}$ & 㐫 & 5 & $\stackrel{\Re}{\stackrel{\circ}{\circ}}$ & $\stackrel{9}{\circ}$ & $\stackrel{\circ}{\circ}$ & 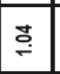 & 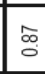 \\
\hline 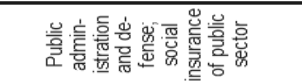 & $\because$ & 咅 & $\stackrel{\infty}{\infty}$ & E & $\cong$ & $\stackrel{\infty}{\circ}$ & \& & 喿 & $\stackrel{9}{\square}$ & 总 & 8 & $\mp$ & : & $\stackrel{ \pm}{\rightleftharpoons}$ & 品 & $\infty$ \\
\hline 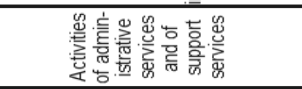 & $\mid$\begin{tabular}{|l|} 
\\
$\infty$ \\
0
\end{tabular} & F & $\stackrel{\infty}{\circ}$ & 桑 & 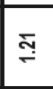 & 䓌 & $\frac{0}{0}$ & 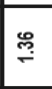 & 离 & $\mathscr{\infty}$ & 管 & 迎 & \begin{tabular}{|l|} 
\\
0 \\
0
\end{tabular} & 萬 & E. & 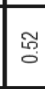 \\
\hline 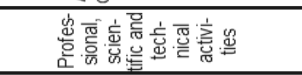 & $\stackrel{?}{F}$ & $\underset{\infty}{\infty}$ & $\stackrel{8}{:}$ & : & : & $\begin{array}{l}\mathbf{a} \\
0 \\
0\end{array}$ & f & : & $\stackrel{8}{8}$ & $\stackrel{?}{\div}$ & 多 & $\stackrel{\leftrightarrow}{s}$ & 总 & ¿ & 多 & $\stackrel{2}{2}$ \\
\hline 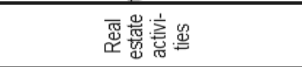 & 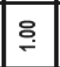 & 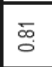 & $\cong$ & f & \begin{tabular}{|l}
$\tilde{N}$ \\
$\tilde{0}$
\end{tabular} & 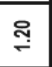 & $\mathscr{\infty}_{\infty}^{\infty}$ & $\stackrel{9}{\%}$ & $\bar{s}$ & $F$ & 每 & สี & $\overline{5}$ & 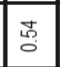 & $?$ & 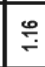 \\
\hline 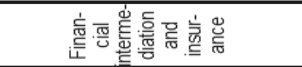 & \% & 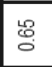 & 5 & ळ & $\stackrel{\circ}{=}$ & 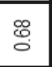 & $\frac{1}{0}$ & 离 & 品 & 荌 & $\begin{array}{l}2 \\
0\end{array}$ & ฐ్ల & $\ddot{\circ}$ & $\begin{array}{l}8 \\
8\end{array}$ & \begin{tabular}{|l|l|}
9 \\
\end{tabular} & $\stackrel{2}{\circ}$ \\
\hline 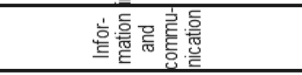 & $\stackrel{\stackrel{m}{=}}{=}$ & $\overline{5}$ & : & 悉 & 否 & \begin{tabular}{|l|}
2 \\
0 \\
\end{tabular} & 学 & \begin{tabular}{|l} 
\\
\end{tabular} & $\overline{5}$ & ¿ & 总 & $\%$ & \begin{tabular}{|l|l}
0 \\
0
\end{tabular} & 范 & $\overline{|c|}$ & 棁 \\
\hline 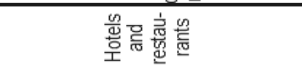 & $\stackrel{9}{?}$ & $\stackrel{8}{9}$ & 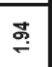 & $\cong$ & $\stackrel{g}{\stackrel{g}{9}}$ & \begin{tabular}{|l|}
$\mathscr{8}$ \\
\end{tabular} & 惫 & 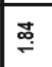 & 遇 & : & 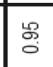 & $\bar{\Phi}$ & $\begin{array}{ll} \\
0\end{array}$ & \begin{tabular}{|l|}
5 \\
5
\end{tabular} & 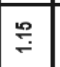 & : \\
\hline 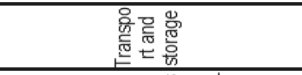 & $\stackrel{\circ}{\stackrel{2}{*}}$ & 兽 & $\overline{\check{I}}$ & $\stackrel{8}{+}$ & $\bar{s}$ & 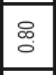 & \begin{tabular}{|l}
9 \\
0 \\
\end{tabular} & $\stackrel{\circ}{\circ}$ & $\dddot{\square}$ & $\stackrel{9}{=}$ & $\bar{s}$ & \begin{tabular}{|l|}
$\dddot{9}$ \\
\end{tabular} & \begin{tabular}{|l|l}
$E$ \\
\end{tabular} & \begin{tabular}{|l|l|}
2 \\
0 \\
\end{tabular} & \begin{tabular}{|l|}
8 \\
\end{tabular} & $\stackrel{?}{:}$ \\
\hline 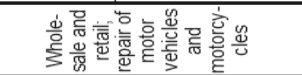 & $\cong$ & $\stackrel{\cong}{-}$ & $\stackrel{\infty}{\dddot{m}}$ & 总 & $\stackrel{?}{:}$ & 品 & 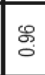 & $\Xi$ & த. & 咹 & 莕 & $\stackrel{9}{\stackrel{9}{+}}$ & 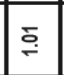 & : & $\stackrel{4}{\circ}$ & $\equiv$ \\
\hline ㅎㅎㅇ흘 & $\dddot{Y}$ & $\begin{array}{l}0 \\
0 \\
0\end{array}$ & $\stackrel{9}{9}$ & E. & 蒿 & 울 & g & 电 & $\stackrel{?}{=}$ & 울 & $\stackrel{0}{\circ}$ & $\stackrel{2}{:}$ & 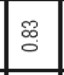 & 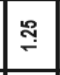 & \begin{tabular}{|l|} 
\\
$\circ$ \\
\end{tabular} & $\begin{array}{l}\infty \\
0 \\
0\end{array}$ \\
\hline 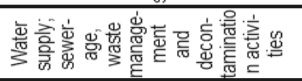 & 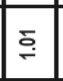 & $\approx$ & $\cong$ & $\stackrel{\infty}{\circ}$ & Б্ & $\overline{\underline{y}}$ & 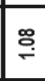 & $\stackrel{\stackrel{\leftrightarrow}{-}}{\circ}$ & $\cong$ & $\stackrel{\overbrace{}}{\stackrel{2}{*}}$ & $\bar{\infty}$ & \begin{tabular}{|l} 
\\
总
\end{tabular} & 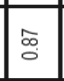 & $\stackrel{\circ}{:}$ & $\begin{array}{l}\because \\
\circ \\
\circ\end{array}$ & \begin{tabular}{|l}
$\mathscr{8}$ \\
$\stackrel{\circ}{\circ}$
\end{tabular} \\
\hline 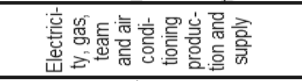 & $\begin{array}{l}\infty \\
\end{array}$ & 桀 & $\stackrel{a}{\underline{0}}$ & 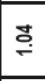 & 哭 & 車 & ฐָ & $\stackrel{9}{9}$ & 官 & \& & $\cong$ & 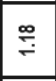 & 足 & $\begin{array}{l}\infty \\
口\end{array}$ & \begin{tabular}{|l|l|}
$\circ$ \\
\\
\end{tabular} & Ẽ \\
\hline & $\stackrel{+}{g}$ & $\stackrel{\infty}{\stackrel{2}{*}}$ & 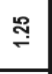 & 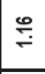 & : & \begin{tabular}{|l|}
$\dot{\infty}$ \\
$\infty$ \\
\end{tabular} & 孚 & E & $\stackrel{\square}{\check{\sigma}}$ & 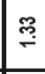 & ب9 & $\because$ & $\underset{0}{E}$ & $\bar{\Xi}$ & $\stackrel{2}{\sim}$ & : \\
\hline 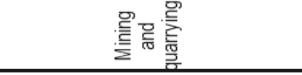 & f & 品 & $\stackrel{8}{\circ}$ & $\stackrel{\circ}{\circ}$ & 产 & \begin{tabular}{|l|l|} 
\\
0 \\
\end{tabular} & $\stackrel{2}{\leftarrow}$ & $\begin{array}{l}8 \\
0 \\
\end{array}$ & $\overline{3}$ & $\stackrel{2}{\%}$ & $\stackrel{2}{\circ}$ & 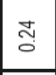 & 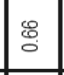 & 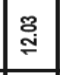 & f & : \\
\hline & $\stackrel{8}{\circ}$ & $\cong$ & $\stackrel{9}{\Im}$ & $\stackrel{ \pm}{\rightleftharpoons}$ & 量 & \begin{tabular}{|l} 
\\
\\
0 \\
\end{tabular} & : & \begin{tabular}{|l}
$\mathscr{8}$ \\
\end{tabular} & $\bar{c}$ & 舀 & 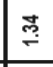 & $\because$ & $\begin{array}{l} \\
0 \\
\end{array}$ & $\dddot{2}$ & $\stackrel{9}{a}$ & I \\
\hline 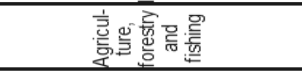 & \begin{tabular}{|l}
2 \\
0 \\
\end{tabular} & $\dddot{T}$ & F & $\stackrel{\leftrightarrow}{\div}$ & 总 & \begin{tabular}{|l|l|}
$\stackrel{2}{\rightleftarrows}$ \\
\end{tabular} & $\stackrel{a}{:}$ & \begin{tabular}{|l|l}
5 \\
\\
\end{tabular} & 草 & E. & 离 & \begin{tabular}{|l|}
5 \\
\end{tabular} & 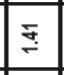 & $\dot{5}$ & \begin{tabular}{|l|l|}
$\infty$ \\
0 \\
\end{tabular} & \begin{tabular}{|ll} 
\\
$\infty$
\end{tabular} \\
\hline 产哥妾 & 1 & L" & & 岁 & ह & & L & 焉 & 产 & 을 & $\mathscr{w}$ & 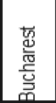 & $\bar{s}$ & Б & 兄 & \\
\hline 惡 & & & & & & & & & & & & 墪 & & & 䓵 & $\underline{\underline{u}}$ \\
\hline
\end{tabular}


Counties and their LQ in 2014

Source: own calculations

\begin{tabular}{|c|c|c|c|c|c|c|c|c|c|c|c|c|}
\hline 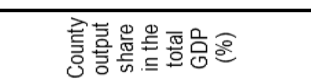 & 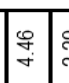 & 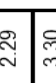 & & एँّ & & & & $\stackrel{\oplus}{\oplus}$ & & & & c \\
\hline 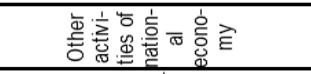 & 101 & 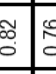 & 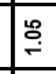 & 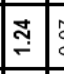 & 0 & $\stackrel{\varpi}{\mp}$ & 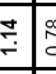 & 5 & $\stackrel{2}{\div}$ & 10 & & \pm \\
\hline 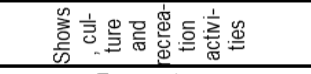 & 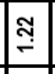 & : & $\stackrel{8}{\circ}$ & $\overline{\underline{y}}$ & & $\cong$ & 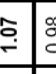 & : & ì & & & \\
\hline 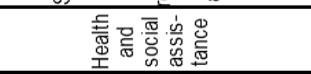 & 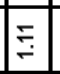 & 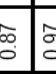 & 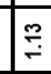 & 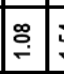 & $\stackrel{8}{0}$ & $\mid$\begin{tabular}{|}
$\mid$ \\
\end{tabular} & 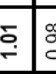 & 3 & 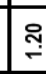 & $\stackrel{5}{=}$ & & $=$ \\
\hline 咅言 & בְּ & : & & 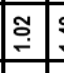 & 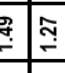 & & בְ: & 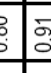 & 8 & 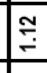 & & \\
\hline 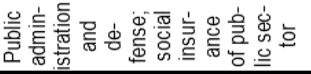 & $:$ & $\begin{array}{lll}0 \\
0\end{array}$ & : & 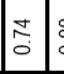 & 管 & $\therefore$ & 象 & {$[0$} & 惫 & 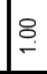 & & 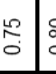 \\
\hline 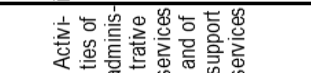 & $\cong$ & $\stackrel{8}{8}$ & & : & 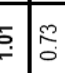 & 9 & 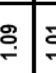 & 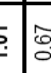 & 舅 & Ta & & 草 \\
\hline 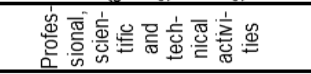 & 染 & 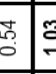 & F & 范 & $\begin{array}{l}0 \\
\end{array}$ & 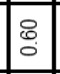 & : & : & 总 & $\sigma^{\circ}$ & & 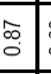 \\
\hline 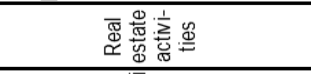 & \begin{tabular}{|l|} 
\\
$\vdots$ \\
0
\end{tabular} & $8:$ & 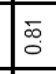 & \begin{tabular}{|l|l|l}
2 \\
0 \\
0
\end{tabular} & $\begin{array}{l}5 \\
\end{array}$ & $\cong$ & 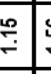 & 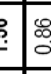 & 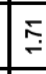 & 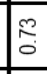 & & \\
\hline 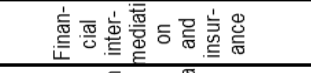 & $\overline{\underline{\prime}}$ & 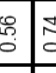 & : & 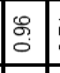 & $\begin{array}{ll}5 \\
\end{array}$ & 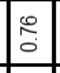 & 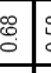 & 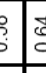 & 悉 & : & 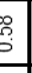 & ¿ \\
\hline 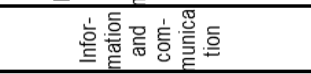 & $\overline{\mathrm{i}}$ & : & 品 & \begin{tabular}{|l|l}
$\mathscr{B}$ \\
\hdashline
\end{tabular} & 策 & 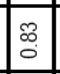 & ב: & $\int_{0}^{2}$ & 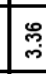 & 唇 & 5 & 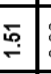 \\
\hline 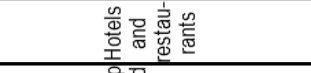 & 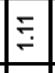 & 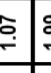 & $\stackrel{-}{-}$ & $\cong$ & $\begin{array}{c}5: 5 \\
\end{array}$ & 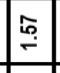 & 实 & 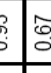 & \pm & E & & \\
\hline 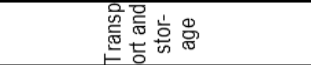 & $\bar{\Phi}$ & 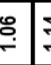 & tִ & 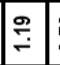 & $\begin{array}{c}0 \\
0 \\
0\end{array}$ & 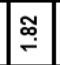 & $\begin{array}{l}8 \\
0 \\
0\end{array}$ & 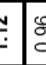 & $\stackrel{\infty}{\stackrel{9}{9}}$ & 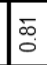 & & 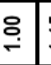 \\
\hline 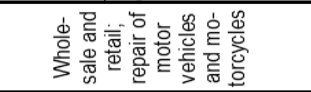 & $\stackrel{2}{-1}$ & 落: & $\stackrel{\square}{\square}$ & 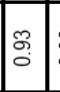 & : & $\stackrel{\varrho}{=}$ & ฮั & ఃू & త్ & & & \\
\hline 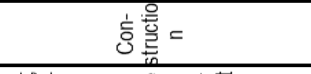 & 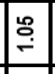 & 5 & ס & 要 & $\underset{5}{5}$ & \pm & : & 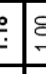 & $\stackrel{\leftrightarrow}{ \pm}$ & $q^{\infty}$ & 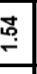 & \\
\hline 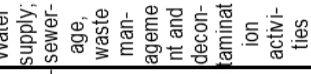 & $\because$ & 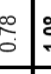 & 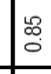 & $:$ & 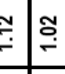 & $\$$ & $\overline{\underline{\Sigma}}$ & & 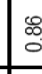 & 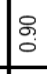 & 7 & \\
\hline 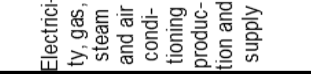 & 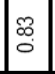 & : & 官 & 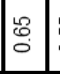 & 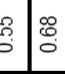 & \begin{tabular}{|l|l|}
\multirow{2}{*}{} \\
\end{tabular} & 萬 & ְू & 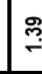 & $ร$ & $\frac{\widetilde{s}}{\mathrm{~s}}$ & \\
\hline 言惑可 & : & ב. & & \begin{tabular}{|l|l|} 
\\
\\
\end{tabular} & \begin{tabular}{l|l} 
\\
\end{tabular} & \begin{tabular}{|l|l|} 
\\
\end{tabular} & ¿ & 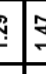 & 总 & $\because$ & & 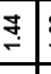 \\
\hline 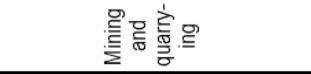 & : & 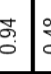 & 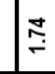 & $\Sigma$ & 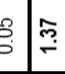 & $: ?$ & 管 & & ¿ & 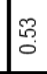 & & \\
\hline 薏立 & : & 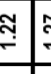 & $\stackrel{9}{+}$ & \begin{tabular}{|l|l|} 
\\
\end{tabular} & $\begin{array}{l}8 \\
5\end{array}$ & $8:$ & 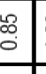 & 15 & 品 & 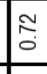 & 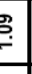 & 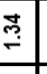 \\
\hline 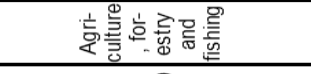 & ב̃ & & $\stackrel{\leftrightarrow}{\circ}$ & & & & \pm & & & & & \\
\hline 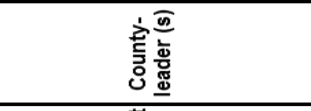 & $\frac{z}{0}$ & & & 䢣 & & & & & & & & \\
\hline & & & & & & & & & & & & \\
\hline
\end{tabular}


reason of this fact is the high level of competitiveness between the information and communication firms in Bucharest, Timis and Cluj. As well, we should take attention to the 'Education' activity. It has become more localized in 2014 (LQ > 1 have 9 counties) than in 2008 (LQ > 1 have 11 counties). It is noteworthy that almost all certain county-leaders in the education sector (Cluj, Mures, Sibiu, lasi, Bacau, Galati, Dolj and Gorj) have increased their specialization.

\section{Conclusions}

This paper aims to consider two tendencies in the economy: the internal integration within the country and the localization of economic activities. We discuss the relationship between the spatial distribution of the economic activity and the integration between the regions of a particular country. In our opinion, the interregional integration within the country intensifies the territorial division of labor and specialization, and the growth of specialization, and, in turn, it strengthens the concentration of activities in certain places. And, as a result of the integration processes, cooperation intensifies, which enhances the development of integration processes. We investigated the spatial interactions within a particular country. In our case, the integrated economic space is the national economy of Romania and its units - macro regions, developed regions and counties. We have discussed the connection between the international and interregional (internal) integration. The reorientation of economic relations from the regions of the country to the foreign trade is an additional factor of reduction for the intra-regional interaction, which hinders the development of territorial labor division, as a result space as if "shrinking". The smaller the size of the necessary for economic activity space, the slower the economic development is being realized, which is further slowing the economic growth.

We have empirically tested three theoretical propositions as regards to the distribution of output and factors of the Romanian economy. The results strongly support the theoretical predictions of an equal-share relationship for the Romanian counties. The calculation of the Spearman rank correlation showed a significant connection between the presence of specific weights of regions in the total output and production factors.

The prediction that the distribution of output and factor shares across counties conforms to a rank-share distribution exhibits the Zipf's law. Also, for the most recent data, the measure of the extent of integration indicated that the level of economic integration between the regions in Romania is gradually increasing. We find a big difference between the NUTS 2 and NUTS 3 interregional integration; therefore it is necessary to investigate regional development on the lower regional level. Also, the small differences between the indicators of integration for the counties and development regions mean that the development regions in Romania represent a correct economic activity. The increase of the integration indicator between the Romanian NUTS 2 and NUTS 3 regions suggests that the effectiveness in the reallocation of resources within the country also increases.

The spatial distribution of the economic activity shows a big concentration of activity in the capital region (Bucharest-Ilfov), but this is a common tendency for the transition countries. The capital metropolis specializes in almost all sectors, except for Agriculture, forestry and fishing and Industry. That means a high level of diversification for the city economy. There are several county-leaders also. These counties attract production factors from other counties, so the leader's share increases, while the other counties' share reduces in the meantime. The analysis of output and factor shares of the Romanian counties during 1995-2014 concludes that the economic activity in Romania grew faster in the Western and Central regions and slower in the Eastern regions.

We can point out that, for the analyzed period, the level of integration of the national economy of Romania has increased, and, at the same time, the specialization level of the leading 
counties by the share in the total GRP has also increased. However, these trends have caused a rising inequality in the distribution of the economic activity.

Appendix

Table A1

Distribution and rank of Romanian counties' output shares during 1995-2014

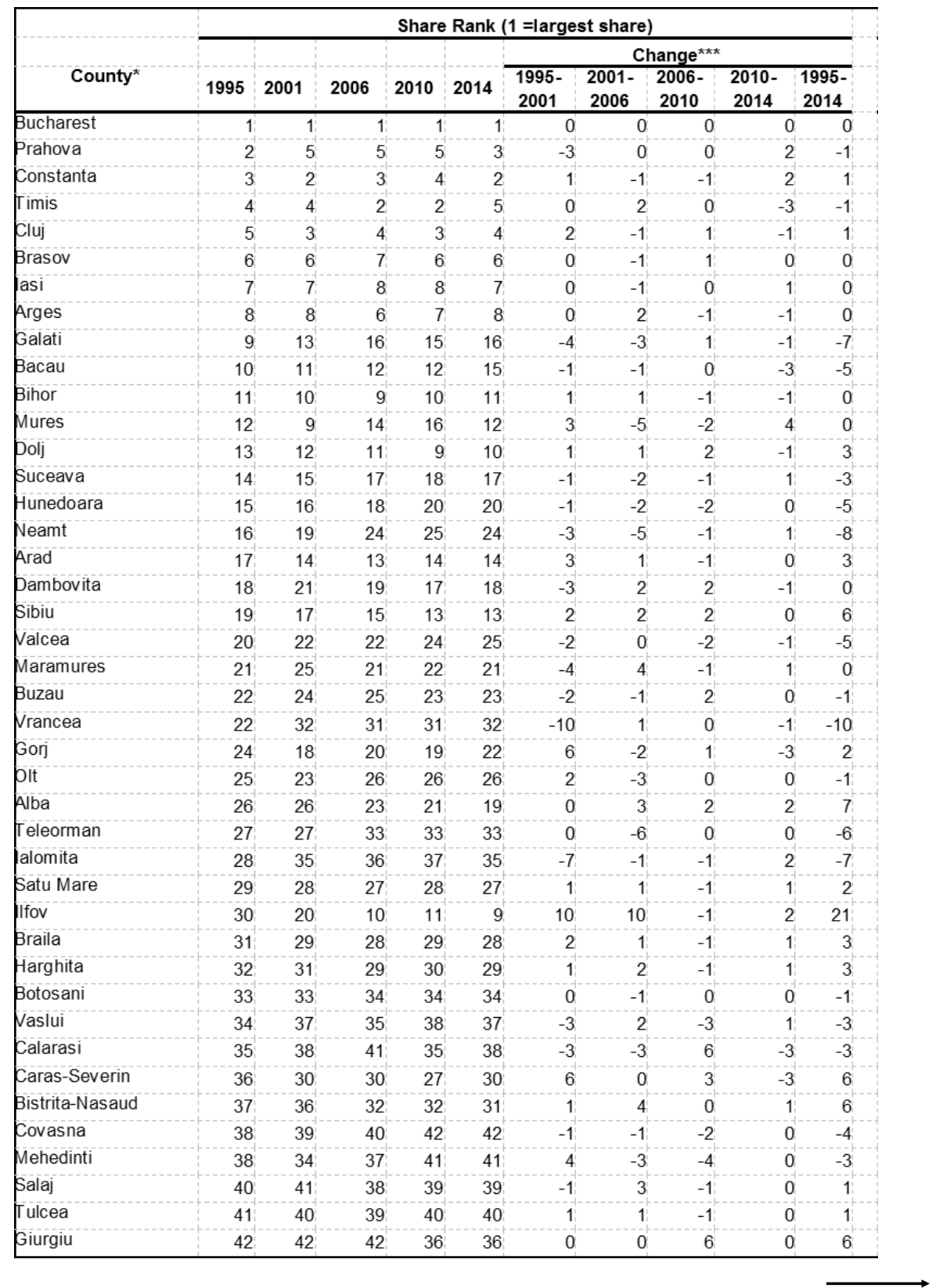


Distribution and rank of Romanian counties' output shares during 1995-2014

\begin{tabular}{|c|c|c|c|c|c|c|c|c|c|c|}
\hline \multirow[b]{3}{*}{ County } & \multicolumn{10}{|c|}{ Share Value ${ }^{\star \star}$} \\
\hline & & & & & & & & Change $^{\star \star x}$ & & \\
\hline & 1995 & 2001 & 2006 & 2010 & 2014 & $\overline{1995-2001}$ & 2001-2006 & 2006-2010 & $2010-2014$ & $1995-2014$ \\
\hline Bucharest & 13.60 & $\overline{19.41}$ & 20.84 & 23.28 & 24.21 & $\overline{5.81}$ & 1.43 & 2.45 & 0.93 & 10.61 \\
\hline Prahova & 4.27 & 3.72 & 3.91 & 3.46 & 4.88 & -0.55 & 0.19 & -0.45 & 1.42 & 0.61 \\
\hline Constanta & 4.14 & 4.17 & 4.33 & 3.98 & 5.07 & 0.03 & 0.16 & -0.35 & 1.09 & 0.93 \\
\hline Timis & 3.54 & 3.79 & 4.42 & 4.86 & 4.46 & 0.25 & 0.63 & 0.44 & -0.40 & 0.92 \\
\hline Cluj & 3.49 & 3.83 & 3.97 & 4.06 & 4.46 & 0.34 & 0.14 & 0.09 & 0.40 & 0.97 \\
\hline Brasov & 3.39 & 3.46 & 3.16 & 3.38 & 3.30 & 0.07 & -0.30 & 0.23 & -0.09 & -0.09 \\
\hline asi & 3.30 & 3.13 & 2.90 & 3.05 & 3.08 & -0.17 & -0.24 & 0.15 & 0.03 & -0.22 \\
\hline Arges & 3.23 & 2.98 & 3.44 & 3.13 & 2.68 & -0.25 & 0.46 & -0.31 & -0.45 & -0.55 \\
\hline Galati & 3.07 & 2.47 & 2.08 & 2.07 & 1.89 & -0.61 & -0.38 & -0.01 & -0.18 & -1.18 \\
\hline Bacau & 3.04 & 2.65 & 2.43 & 2.28 & 1.92 & -0.39 & -0.22 & -0.15 & -0.36 & -1.12 \\
\hline Binor & 2.81 & 2.75 & 2.85 & 2.52 & 2.29 & -0.06 & 0.10 & -0.33 & -0.23 & -0.52 \\
\hline Mures & 2.65 & 2.75 & 2.38 & 2.06 & 2.16 & 0.10 & -0.37 & -0.32 & 0.10 & -0.49 \\
\hline Dolj & 2.64 & 2.59 & 2.53 & 2.55 & 2.48 & -0.05 & -0.06 & 0.02 & -0.07 & -0.16 \\
\hline Suceava & 2.35 & 2.20 & 2.03 & 1.88 & 1.83 & -0.15 & -0.18 & -0.15 & -0.04 & -0.52 \\
\hline Hunedoara & 2.29 & 2.10 & 2.02 & 1.77 & 1.63 & -0.19 & -0.08 & -0.25 & -0.14 & -0.65 \\
\hline Neamt & 2.22 & 1.84 & 1.66 & 1.36 & 1.32 & -0.39 & -0.17 & -0.30 & -0.04 & -0.90 \\
\hline Arad & 2.20 & 2.33 & 2.38 & 2.19 & 2.07 & 0.12 & 0.06 & -0.20 & -0.12 & -0.13 \\
\hline pambovita & 2.18 & 1.75 & 1.83 & 1.94 & 1.74 & -0.43 & 0.08 & 0.11 & -0.21 & -0.44 \\
\hline Sibiu & 1.97 & 2.06 & 2.24 & 2.20 & 2.08 & 0.10 & 0.18 & -0.04 & -0.12 & 0.12 \\
\hline Nalcea & 1.90 & 1.70 & 1.67 & 1.41 & 1.29 & -0.21 & -0.03 & -0.26 & -0.12 & -0.62 \\
\hline Maramures & 1.87 & 1.57 & 1.68 & 1.60 & 1.63 & -0.30 & 0.11 & -0.08 & 0.03 & -0.24 \\
\hline Buzau & 1.79 & 1.66 & 1.53 & 1.47 & 1.41 & -0.13 & -0.13 & -0.06 & -0.06 & -0.37 \\
\hline Nrancea & 1.79 & 1.23 & 1.18 & 1.08 & 1.01 & -0.56 & -0.05 & -0.10 & -0.07 & -0.78 \\
\hline Gorj & 1.76 & 1.92 & 1.71 & 1.83 & 1.49 & 0.16 & -0.21 & 0.12 & -0.33 & -0.26 \\
\hline pitt & 1.76 & 1.69 & 1.32 & 1.34 & 1.27 & -0.07 & -0.37 & 0.03 & -0.08 & -0.49 \\
\hline Alba & 1.73 & 1.54 & 1.66 & 1.75 & 1.65 & -0.19 & 0.12 & 0.09 & -0.10 & -0.08 \\
\hline Teleorman & 1.71 & 1.50 & 1.09 & 1.05 & 1.00 & -0.21 & -0.42 & -0.03 & -0.05 & -0.71 \\
\hline alomita & 1.64 & 1.07 & 0.94 & 0.92 & 0.92 & -0.57 & -0.13 & -0.02 & 0.01 & -0.72 \\
\hline Satu Mare & 1.53 & 1.50 & 1.29 & 1.18 & 1.21 & -0.03 & -0.20 & -0.11 & 0.04 & -0.32 \\
\hline Ifov & 1.52 & 1.75 & 2.54 & 2.45 & 2.57 & 0.24 & 0.79 & -0.09 & 0.11 & 1.05 \\
\hline Braila & 1.50 & 1.34 & 1.28 & 1.17 & 1.10 & -0.16 & -0.06 & -0.11 & -0.07 & -0.40 \\
\hline Harghita & 1.47 & 1.25 & 1.27 & 1.11 & 1.06 & -0.23 & 0.03 & -0.16 & -0.05 & -0.41 \\
\hline Botosani & 1.36 & 1.16 & 1.02 & 1.03 & 0.99 & -0.20 & -0.14 & 0.00 & -0.03 & -0.37 \\
\hline Vaslui & 1.30 & 1.06 & 0.95 & 0.91 & 0.90 & -0.24 & -0.11 & -0.04 & -0.01 & -0.40 \\
\hline Calarasi & 1.28 & 1.00 & 0.79 & 1.02 & 0.88 & -0.28 & -0.21 & 0.23 & -0.15 & -0.41 \\
\hline Caras-Severin & 1.27 & 1.32 & 1.26 & 1.25 & 1.02 & 0.05 & -0.06 & -0.01 & -0.23 & -0.24 \\
\hline Bistrita-Nasaud & 1.20 & 1.07 & 1.17 & 1.07 & 1.02 & -0.14 & 0.11 & -0.10 & -0.06 & -0.19 \\
\hline Covasna & 1.10 & 0.98 & 0.80 & 0.73 & 0.71 & -0.12 & -0.18 & -0.08 & -0.02 & -0.40 \\
\hline Mehedinti & 1.10 & 1.10 & 0.93 & 0.81 & 0.71 & 0.00 & -0.17 & -0.12 & -0.10 & -0.39 \\
\hline Salaj & 1.02 & 0.85 & 0.90 & 0.85 & 0.86 & -0.17 & 0.05 & -0.06 & 0.01 & -0.15 \\
\hline Túcea & 0.95 & 0.86 & 0.86 & 0.85 & 0.77 & -0.10 & 0.00 & -0.01 & -0.08 & -0.18 \\
\hline Giurgiu & 0.90 & 0.85 & 0.71 & 0.99 & 0.90 & -0.05 & -0.15 & 0.29 & -0.09 & 0.01 \\
\hline
\end{tabular}


Table A2

Distribution and rank of Romanian development regions' output shares during 1995-2014

\begin{tabular}{|c|c|c|c|c|c|c|c|c|c|c|c|c|c|c|c|c|c|c|c|c|}
\hline \multirow[b]{3}{*}{ Region $^{*}$} & \multicolumn{10}{|c|}{ Share Rank ( 1 =largest share) } & \multicolumn{10}{|c|}{ Share Value ${ }^{\star \star}$} \\
\hline & & & & & & & & ${\text { Change }{ }^{x}}^{x}$ & $e^{\star \star \star}$ & & & & & & & & & hange $e^{\star \star z}$ & & \\
\hline & 1995 & 2001 & 1200 & 20 & \begin{tabular}{l|l}
0 & 2014
\end{tabular} & \begin{tabular}{|l|l|}
1995 \\
4 & 2001 \\
\end{tabular} & \begin{tabular}{|l|l|} 
& $2001-$ \\
1 & 2006 \\
\end{tabular} & \begin{tabular}{ll|}
$1-2006-$ \\
6 & 2010 \\
\end{tabular} & \begin{tabular}{|l|l|}
0 & $2010-$ \\
0 & 2014 \\
\end{tabular} & $\begin{array}{l}1995- \\
2014 \\
\end{array}$ & 1995 & 2001 & 2006 & 2010 & 2014 & \begin{tabular}{|l|}
$1995-$ \\
2001 \\
\end{tabular} & \begin{tabular}{|l|}
$2001-$ \\
2006
\end{tabular} & $\begin{array}{l}2006- \\
2010\end{array}$ & \begin{tabular}{|l|}
$2010-$ \\
2014
\end{tabular} & \begin{tabular}{|l|}
$1995-$ \\
2014 \\
\end{tabular} \\
\hline $\begin{array}{l}\text { South - } \\
\text { Muntenia }\end{array}$ & & 1 & 2 & 2 & 2 & 2 & -1 & 0 & 0 & -1 & 15.2 & 12.87 & 12.69 & 12.51 & 12.99 & -2.33 & -0.18 & -0.18 & 0.48 & -2.21 \\
\hline $\begin{array}{l}\text { Bucharest } \\
\text { lfov }\end{array}$ & & 2 & 1 & 1 & 1 & 1 & 1 & 0 & 0 & 1 & 15.11 & 21.16 & 23.38 & 25.73 & 26.78 & 6.05 & 2.22 & 2.35 & 1.05 & 11.67 \\
\hline North-East & & 3 & 3 & 6 & 6 & 6 & $a$ & -3 & 0 & -3 & 13.58 & 12.04 & 10.98 & 10.5 & 10.05 & -1.54 & $\begin{array}{l}-1.06 \\
\end{array}$ & -0.48 & -0.45 & -3.53 \\
\hline $\begin{array}{l}\text { South - } \\
\text { East }\end{array}$ & & 4 & 5 & 5 & 5 & 4 & -1 & 0 & 0 & 0 & 13.24 & 41.72 & 11.26 & 10.63 & 11.26 & -1.52 & -0.46 & -0.63 & 0.63 & -1.98 \\
\hline Cénter & & 5 & 3 & 4 & 4 & 5 & 2 & $\begin{array}{l}-1 \\
-1 \\
-1\end{array}$ & $\alpha$ & 0 & 12.3 & 12.04 & 11.51 & 11.23 & 10.96 & -0.26 & -0.53 & -0.28 & -0.27 & -1.34 \\
\hline $\begin{array}{l}\text { Noirth } \\
\text { West }\end{array}$ & & 6 & 6 & 3 & 3 & 3 & a & 3 & 0 & 3 & 11.91 & 11.56 & 11.87 & 11.28 & 11.47 & -0.35 & 0.31 & -0.59 & 0.19 & -0.44 \\
\hline West & & 7 & 7 & 7 & 7 & 7 & $a$ & 0 & 0 & 0 & 9.29 & 9.53 & 10.09 & 10.06 & 9.18 & 0.24 & 0.56 & -0.03 & -0.88 & -0.11 \\
\hline $\begin{array}{l}\text { South- } \\
\text { Vest OI- } \\
\text { enia }\end{array}$ & & 8 & 8 & 8 & 8 & 8 & a & $\alpha$ & $\alpha$ & a & 9.15 & $9 !$ & 8.15 & 7.94 & 7.23 & -0.15 & -0.85 & -0.21 & -0.71 & -1.92 \\
\hline
\end{tabular}

Table A3

Distribution and rank of Romanian counties' employment shares during 1995-2014

\begin{tabular}{|c|c|c|c|c|c|c|c|c|c|c|}
\hline \multirow[b]{3}{*}{ Region $^{*}$} & \multicolumn{10}{|c|}{ Share Rank (1 =largest share) } \\
\hline & & & & & & & & Change $^{\star \star \star}$ & & \\
\hline & 1995 & 2001 & 2006 & 2010 & 2014 & 1995-2001 & $2001-2006$ & $2006-2010$ & $2010-2014$ & $1995-2014$ \\
\hline Bucharest & 1 & 1 & 1 & 1 & 1 & 0 & 0 & & 0 & \\
\hline Prahova & 2 & 5 & 5 & 4 & 5 & -3 & 0 & 1 & -1 & \\
\hline lasi & 3 & 2 & 4 & 6 & 6 & 1 & -2 & -2 & 0 & \\
\hline Cluj & 4 & 4 & 3 & 2 & 2 & 0 & 1 & & 0 & \\
\hline Constanta & 5 & 7 & 6 & 5 & 4 & -2 & 1 & 1 & 1 & 1 \\
\hline Timis & 6 & 6 & 2 & 3 & 3 & 0 & 4 & -1 & 0 & 5 \\
\hline Arges & 7 & 10 & 9 & 9 & 9 & -3 & 1 & & 0 & \\
\hline Dolj & 8 & 3 & 7 & 7 & 7 & 5 & -4 & & 0 & \\
\hline Suceava & 9 & 8 & 10 & 10 & 11 & 1 & -2 & 0 & -1 & \\
\hline Bacau & 10 & 11 & 13 & 13 & 13 & -1 & -2 & & 0 & \\
\hline Galati & 11 & 15 & 14 & 18 & 17 & -4 & 1 & & 1 & \\
\hline Mures & 12 & 14 & 11 & 11 & 12 & -2 & 3 & & -1 & \\
\hline Brasov & 13 & 12 & 12 & 12 & 10 & 1 & 0 & & 2 & \\
\hline Hunedoara & 14 & 18 & 19 & 19 & 20 & -4 & -1 & & -1 & \\
\hline Neamt & 15 & 13 & 17 & 17 & 18 & 2 & -4 & & -1 & \\
\hline Bihor & 16 & 9 & 8 & 8 & 8 & 7 & 1 & & 0 & 5 \\
\hline Maramures & 17 & 16 & 18 & 16 & 15 & 1 & -2 & & 1 & \\
\hline Dambovita & 18 & 17 & 16 & 14 & 16 & 1 & 1 & & -2 & \\
\hline Arad & 19 & 21 & 15 & 14 & 14 & -2 & 6 & & 0 & \\
\hline Valcea & 20 & 23 & 24 & 22 & 25 & -3 & -1 & & -3 & \\
\hline blt & 21 & 20 & 23 & 23 & 22 & 1 & -3 & & 1 & \\
\hline Buzau & 22 & 19 & 20 & 20 & 20 & 3 & -1 & & 0 & b \\
\hline Teleorman & 23 & 22 & 25 & 25 & 26 & 1 & -3 & & -1 & \\
\hline Botosani & 24 & 24 & 27 & 28 & 28 & 0 & -3 & -1 & 0 & \\
\hline Gorj & 25 & 28 & 29 & 31 & 31 & -3 & -1 & -2 & 0 & 5 \\
\hline Alba & 26 & 25 & 21 & 24 & 24 & 1 & 4 & -3 & 0 & \\
\hline Vaslui & 27 & 26 & 26 & 27 & 28 & 1 & 0 & -1 & -1 & \\
\hline Sibiu & 28 & 27 & 22 & 21 & 19 & 1 & 5 & 1 & 2 & \\
\hline Vrancea & 29 & 30 & 30 & 30 & 30 & -1 & 0 & & 0 & 5 \\
\hline Satu Mare & 30 & 29 & 28 & 29 & 27 & 1 & 1 & & 2 & \\
\hline Caras-Severin & 31 & 32 & 35 & 35 & 35 & -1 & -3 & & 0 & 5 \\
\hline Braila & 32 & 33 & 33 & 33 & 34 & -1 & 0 & & -1 & \\
\hline Harghita & 33 & 31 & 32 & 32 & 32 & 2 & -1 & & 0 & b \\
\hline Bistrita-Nasaud & 34 & 35 & 34 & 34 & 33 & -1 & 1 & & 1 & \\
\hline Mehedinti & 35 & 34 & 36 & 36 & 36 & 1 & -2 & 0 & 0 & b \\
\hline Calarasi & 36 & 36 & 37 & 37 & 38 & 0 & -1 & & -1 & \\
\hline alomita & 37 & 37 & 38 & 39 & 38 & 0 & -1 & -1 & 1 & 1 \\
\hline Tulcea & 38 & 41 & 40 & 42 & 42 & -3 & 1 & -2 & 0 & \\
\hline Covasna & 39 & 42 & 41 & 41 & 41 & -3 & 1 & 0 & 0 & 5 \\
\hline Salaj & 40 & 39 & 39 & 38 & 37 & 1 & 0 & 1 & 1 & 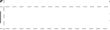 \\
\hline Giurgiu & 41 & 40 & 42 & 40 & 40 & 1 & -2 & 2 & 0 & \\
\hline Ifov & 42 & 38 & 31 & 26 & 23 & 4 & 7 & 5 & 3 & 3 \\
\hline
\end{tabular}


Ihor YASKAL, Liviu-George MAHA, Oksana PETRASHCHAK

Table $A 3$

Distribution and rank of Romanian counties' employment shares during 1995-2014

\begin{tabular}{|c|c|c|c|c|c|c|c|c|c|c|}
\hline \multirow[b]{3}{*}{ Region ${ }^{*}$} & \multicolumn{10}{|c|}{ Share Value $e^{\text {t*t }}$} \\
\hline & & & & & & & & Change $e^{ \pm \times x \neq}$ & & \\
\hline & 1995 & 2001 & 2006 & 2010 & 2014 & 1995-2001 & 2001-2006 & $2006-2010$ & $2010-2014$ & \begin{tabular}{|l|l|}
$1995-2014$ \\
\end{tabular} \\
\hline Bucharest & 7.91 & 8.21 & 11.35 & 12.03 & 12.41 & 0.30 & 3.14 & 0.68 & 0.38 & 4.5 \\
\hline Prahova & 4.00 & 3.50 & 3.47 & 3.49 & 3.39 & -0.50 & -0.03 & 0.01 & -0.09 & -0.6 \\
\hline lasi & 3.74 & 3.72 & 3.49 & 3.41 & 3.31 & -0.02 & -0.23 & -0.08 & -0.10 & -0.43 \\
\hline Cluj & 3.31 & 3.51 & 3.65 & 3.80 & 3.97 & 0.20 & 0.15 & 0.15 & 0.17 & 0.66 \\
\hline Constanta & 3.27 & 3.24 & 3.45 & 3.44 & 3.41 & -0.03 & 0.21 & -0.01 & -0.03 & 0.1 \\
\hline Timis & 3.18 & 3.31 & 3.71 & 3.68 & 3.83 & 0.13 & 0.40 & -0.03 & 0.15 & 0.64 \\
\hline Arges & 3.12 & 3.09 & 2.97 & 2.90 & 2.91 & -0.04 & -0.12 & -0.07 & 0.01 & -0.2 \\
\hline Dolj & 3.12 & 3.52 & 3.23 & 3.30 & 3.19 & 0.41 & -0.30 & 0.07 & -0.11 & 0.07 \\
\hline Suceava & 3.08 & 3.16 & 2.81 & 2.86 & 2.77 & 0.08 & -0.35 & 0.05 & -0.09 & -0.3 \\
\hline Bacau & 3.04 & 2.94 & 2.67 & 2.52 & 2.46 & -0.11 & -0.27 & -0.15 & -0.06 & -0.58 \\
\hline Galati & 2.92 & 2.70 & 2.45 & 2.28 & 2.27 & -0.23 & -0.25 & -0.17 & -0.01 & -0.64 \\
\hline Mures & 2.84 & 2.72 & 2.79 & 2.76 & 2.74 & -0.12 & 0.07 & -0.04 & -0.01 & -0.10 \\
\hline Brasov & 2.82 & 2.80 & 2.76 & 2.73 & 2.82 & -0.02 & -0.04 & -0.02 & 0.09 & 0.00 \\
\hline Hunedoara & 2.73 & 2.41 & 2.30 & 2.17 & 2.13 & -0.33 & -0.10 & -0.14 & -0.04 & -0.6 \\
\hline Neamt & 2.71 & 2.77 & 2.31 & 2.30 & 2.22 & 0.06 & -0.46 & -0.01 & -0.08 & -0.4 \\
\hline Binor & 2.70 & 3.09 & 3.15 & 3.14 & 3.08 & 0.39 & 0.06 & 0.00 & -0.06 & 0.38 \\
\hline Maramures & 2.35 & 2.42 & 2.31 & 2.31 & 2.32 & 0.07 & -0.11 & 0.00 & 0.01 & -0.0 \\
\hline Dambovita & 2.21 & 2.41 & 2.37 & 2.35 & 2.30 & 0.20 & -0.04 & -0.02 & -0.05 & 0.09 \\
\hline Arad & 2.20 & 2.18 & 2.37 & 2.35 & 2.45 & -0.02 & 0.19 & -0.02 & 0.10 & 0.2 \\
\hline Valcea & 2.17 & 2.12 & 1.96 & 2.00 & 1.92 & -0.05 & -0.16 & 0.04 & -0.08 & -0.28 \\
\hline bit & 2.17 & 2.22 & 2.03 & 1.96 & 1.97 & 0.05 & -0.19 & -0.07 & 0.01 & -0.2 \\
\hline Buzau & 2.15 & 2.32 & 2.18 & 2.14 & 2.13 & 0.17 & -0.15 & -0.04 & -0.01 & -0.02 \\
\hline Teleorman & 2.07 & 2.16 & 1.93 & 1.90 & 1.90 & 0.09 & -0.23 & -0.02 & 0.00 & -0.1 \\
\hline Botosani & 2.01 & 2.08 & 1.79 & 1.72 & 1.71 & 0.07 & -029 & -0.07 & -0.01 & -0.30 \\
\hline Gorj & 1.97 & 1.85 & 1.68 & 1.64 & 1.59 & -0.12 & -0.17 & -0.04 & -0.05 & -0.38 \\
\hline Alba & 1.93 & 2.05 & 2.06 & 1.94 & 1.93 & 0.12 & 0.01 & -0.12 & -0.01 & 0.00 \\
\hline Vaslui & 1.93 & 2.03 & 1.82 & 1.74 & 1.71 & 0.10 & -0.22 & -0.07 & -0.03 & -0.22 \\
\hline Sibiu & 1.91 & 1.95 & 2.03 & 2.07 & 2.15 & 0.04 & 0.08 & 0.04 & 0.08 & 0.2 \\
\hline Vrancea & 1.86 & 1.74 & 1.66 & 1.71 & 1.65 & -0.12 & -0.08 & 0.04 & -0.06 & -0.2 \\
\hline Satu Mare & 1.76 & 1.78 & 1.71 & 1.72 & 1.75 & 0.02 & -0.06 & 0.00 & 0.03 & -0.0 \\
\hline Caras-Severin & 1.75 & 1.62 & 1.41 & 1.39 & 1.32 & -0.13 & -021 & -0.02 & -0.07 & -0.4 \\
\hline Braila & 1.63 & 1.56 & 1.51 & 1.50 & 1.45 & -0.07 & -0.05 & -0.02 & -0.05 & -0.18 \\
\hline Harghita & 1.61 & 1.63 & 1.56 & 1.61 & 1.56 & 0.02 & -0.07 & 0.05 & -0.05 & -0.0 \\
\hline Bistrita-Nasaud & 1.41 & 1.44 & 1.42 & 1.49 & 1.51 & 0.03 & -0.02 & 0.07 & 0.02 & 0.1 \\
\hline Mehedinti & 1.38 & 1.51 & 1.38 & 1.30 & 1.29 & 0.13 & -0.13 & -0.08 & -0.01 & -0.0 \\
\hline Calarasi & 1.33 & 1.30 & 1.22 & 1.22 & 1.17 & -0.04 & -0.08 & 0.00 & -0.05 & -0.11 \\
\hline alomita & 1.26 & 1.26 & 1.20 & 1.18 & 1.17 & 0.00 & -0.06 & -0.02 & -0.01 & -0.0 \\
\hline Tulcea & 120 & 1.09 & 1.03 & 0.97 & 0.98 & -0.11 & -0.06 & -0.06 & 0.01 & -0.22 \\
\hline Covasna & 1.17 & 1.03 & 1.03 & 1.00 & 1.00 & -0.14 & 0.00 & -0.03 & 0.00 & -0.17 \\
\hline Salaj & 1.14 & 1.22 & 1.19 & 1.18 & 1.20 & 0.08 & -0.04 & -0.01 & 0.02 & 0.08 \\
\hline Giurgiu & 1.10 & 1.14 & 1.02 & 1.04 & 1.04 & 0.04 & -0.12 & 0.01 & 0.01 & -0.0 \\
\hline lifov & 1.08 & 1.23 & 1.59 & 1.80 & 1.95 & 0.15 & 0.36 & 0.20 & 0.15 & 0.87 \\
\hline
\end{tabular}


Distribution and rank of Romanian development regions' employment shares during 1995-2014

\begin{tabular}{|c|c|c|c|c|c|c|c|c|c|c|c|c|c|c|c|c|c|c|c|c|c|}
\hline \multirow[b]{3}{*}{ Region $^{*}$} & \multirow[b]{3}{*}{1995} & \multicolumn{10}{|c|}{ Share Rank (1 =largest share) } & \multicolumn{10}{|c|}{ Share Value ${ }^{\star \star}$} \\
\hline & & & & & & & & Chan & $\operatorname{lng}^{\star \star \star \star}$ & & & & & & & & & & Change ${ }^{\star \star x}$ & & \\
\hline & & 2001 & $1 \quad 200$ & O 2010 & 2014 & $4 \begin{array}{l}1995- \\
2001\end{array}$ & $2001-$ & $\begin{array}{l}-2006- \\
2010\end{array}$ & $2010-2014$ & \begin{tabular}{l|l}
4 & $1995-201$ \\
\end{tabular} & & 1995 & 2001 & 2006 & 2010 & 2014 & $\begin{array}{l}1995- \\
2001\end{array}$ & $\begin{array}{l}2001- \\
2006\end{array}$ & $\begin{array}{l}2006- \\
2010\end{array}$ & $\begin{array}{l}2010- \\
2014\end{array}$ & $\begin{array}{l}1995- \\
2014\end{array}$ \\
\hline North - East & 1 & & 1 & 1 & 1 & 2 & 0 & 0 & 0 & -1 & -1 & 16.52 & 16.7 & 14.88 & 14.55 & $\overline{5.14 .18}$ & $\begin{array}{ll}8 & 0.18 \\
\end{array}$ & -1.82 & $32-0.33$ & $\begin{array}{cc}3-0.37 \\
\end{array}$ & -2.34 \\
\hline South - Muntenia & 2 & & 2 & 2 & 2 & 3 & 0 & 0 & 0 & -1 & -1 & 15.09 & 14.85 & 14.17 & 14.07 & 13.88 & $\begin{array}{ll}8 & -0.24 \\
\end{array}$ & -0.68 & $88-0.1$ & $\begin{array}{l}1 \\
-0.19\end{array}$ & -1.21 \\
\hline South-East & 3 & & 4 & 5 & 6 & 6 & 1 & & -1 & 0 & -3 & 13.04 & 12.65 & 12.28 & 12.03 & B 11.89 & $9-0.39$ & -0.37 & $37-0.25$ & $5=0.14$ & -1.15 \\
\hline North-West & 4 & & 3 & 3 & 4 & 4 & 1 & 0 & -1 & 0 & 0 & 12.66 & 13.45 & 13.42 & 13.63 & 313.83 & $\begin{array}{l}3 \quad 0.79 \\
\end{array}$ & -0.03 & 30.21 & 0.2 & 1.17 \\
\hline Center & 5 & & 5 & 6 & $5 \quad 5$ & 5 & 0 & 1 & 1 & 0 & 0 & 12.28 & 12.17 & 12.23 & 12.11 & 12.2 & $2-0.11$ & 0.06 & $66-0.12$ & 20.09 & -0.08 \\
\hline $\begin{array}{l}\text { South - West ÖI- } \\
\text { tenia }\end{array}$ & 6 & & 6 & 7 & 7 & 7 & -1 & & 0 & 0 & -1 & 10.81 & 11.22 & 10.27 & 10.2 & $\begin{array}{l}29.95 \\
\end{array}$ & $\begin{array}{ll}5 & 0.41\end{array}$ & -0.95 & $\begin{array}{ll}35 & -0.07\end{array}$ & 7 -0.25 & -0.86 \\
\hline West & 7 & & 7 & 8 & $8 \quad 8$ & 8 & 0 & 1 & 0 & 0 & -1 & 9.86 & 9.52 & 9.8 & 9.59 & $9 \quad 9.73$ & $\begin{array}{ll}3 & -0.34 \\
\end{array}$ & 0.28 & $28-0.21$ & 0.14 & -0.13 \\
\hline Bucharest - llfov & 8 & & 8 & 4 & 3 & 1 & 0 & 4 & 1 & 2 & 7 & 9.74 & 9.44 & 12.94 & 13.83 & B 14.35 & $\begin{array}{ll}5 & -0.3\end{array}$ & 3.5 & $\begin{array}{ll}5 & 0.89\end{array}$ & 0.52 & 4.61 \\
\hline
\end{tabular}

Source: own calculations

*Sorted by rank in 1995

** Share values in percent

${ }^{* * *} A$ positive change indicates a higher rank in the end year relative to the start year

${ }^{* * * *} A$ positive value indicates a higher share value in the end year relative to the start year

\section{References}

ANTONESCU D. (2012), Identifying regional disparities in Romania: a convergence process perspective in relation to European Union's territorial structures, Procedia Economics and Finance 3, 1148-1155.

BEHRENS K., THISSE J.-F. (2007), Regional economics: A new economic geography perspective, Regional Science and Urban Economics 37 (4), 457-465.

BILLINGS S. B., JOHNSON E. B. (2012), A non-parametric test for industrial specialization, Journal of Urban Economics 71 (3), 312-331.

BILLINGS S. B., JOHNSON E. B. (2016), Agglomeration within an urban area, Journal of Urban Economics 91 (10), 13-25.

BOWEN H. P., MUNANDAR H., VIAENE J.-M. (2010), How integrated is the world economy?, Review of World Economics, 146 (3), 389-414.

BOWEN H. P., MUNANDAR H., VIAENE J.-M. (2011), Are EU countries less integrated than U.S. States? Theory and evidence, Journal of Regional Science 51 (4), 653-677.

DACHIN A., POPA R. (2011), Regional disparities in employment structures and productivity in Romania, Romanian Journal of Regional Science 5 (2), 65-75.

DEVEREUX M. P., GRIFFITH R., SIMPSON H. (2004), The Geographic Distribution of Production Activity in the UK, Regional Science and Urban Economics 34 (5), 533-564.

DURANTON G., OVERMAN H. G. (2005), Testing for Localisation Using Micro-Geographic Data, Review of Economic Studies 72 (4), 1077-1106.

EICHENGREEN B. (2016), Globalization's Last Gasp, Project Sindicate, Available at: https://www.project-syndicate.org/commentary/growth-before-globalization-by-barryeichengreen-2016-11.

ELLISON G., GLAESER E. L. (1997), Geographic Concentration in U.S. Manufacturing Industries: A Dartboard Approach, Journal of Political Economy 105 (5), 889-927.

EUROSTAT (2016), Eurostat Regional Yearbook, Publications office of the European Union, Luxembourg.

FESER E. J., SWEENEY S. H. (2002), Theory, methods, and a cross-metropolitan comparison of business clustering, in: McCann P. (ed.), Industrial Location Economics, Edward Elgar, Cheltenham, pp. 221-259.

FRATESI U. (2008), Issues in the measurement of localization, Environment and Planning A: Economy and Space 40 (3), 733-758. 
FREY M., WIESLHUBER C. (2011), Do Kazakh regions converge?, Kurzanalysen und Informationen 52, 1-7.

GAROFALO G. A., YAMARIK S. (2002), Regional convergence: Evidence from a new stateby-state capital stock series, Review of Economics and Statistics 84 (2), 316-323.

GHOSH M. (2008), Economic reforms, growth and regional divergence in India, Margin: The Journal of Applied Economic Research 2 (3), 265-285.

GOLLEY J., GROENEWOLD N. (2007), Domestic Market Integration and Inter-regional Growth Spillovers, in: Garnaut R., Song L. (eds.), China - Linking Markets for Growth, Asia Pacific Press, Canberra, pp. 176-196.

HERRMANN-PILLATH C., LIBMAN A., YU X. (2014), Economic integration in China: Politics and culture, Journal of Comparative Economics 42 (2), 470-492. HINES C. (2000), Localization: A Global Manifesto, Earthscan, London.

HUANG S., FIDRMUC J., FIDRMUC J. (2015), Whither China? Reform and economic integration among Chinese regions, China Economic Review 33, 94-110.

KULLBACK S., LEIBLER R. A. (1951), On information and sufficiency, The Annals of Mathematical Statistics 22 (1), 79-86.

LIAO W.-C. (2012), Inshoring: The geographic fragmentation of production and inequality, Journal of Urban Economics 72 (1), 1-16. MARCON E., PUECH F. (2010), Measures of the geographic concentration of industries: improving distance-based methods, Journal of Economic Geography 10 (5), 745-762. MAUREL F., SÉDILLOT B. (1999), A measure of the geographic concentration in French manufacturing industries, Regional Science and Urban Economics 29 (5), 575-604. MCCORD G. C., SACHS J. D. (2013), Development, structure, and transformation: some evidence on comparative economic growth, NBER Working Paper No. 19152, 1-37. MORI T., NISHIKIMI K., SMITH T. E. (2005), A divergence statistic for industrial localization, Review of Economics and Statistics 87 (4), 635-651. MORRISSEY K. (2016), A location quotient approach to producing regional production multipliers for the Irish economy, Papers in Regional Science 95 (3), 491-506.

MOTA I., BRANDÃO A. (2013), The determinants of location choice: Single plants versus multi-plants, Papers in Regional Science 92 (1), 31-49.

MUNNELL A. H. (1990), Why has productivity growth declined? Productivity and public investment, New England Economic Review January/February, 3-22.

PIKE A., RODRÍGUEZ-POSE A., TOMANEY J. (2016), Shifting horizons in local and regional development, Regional Studies 51 (1), 46-57.

PONCET S., BARTHÉLEMY J. (2008), China as an Integrated Area?, Journal of Economic Integration 23 (4), 896-926.

RESMINI L. (2003), Economic integration, industry location and frontier economies in transition countries, Economic Systems 27 (2), 205-221.

RODRIGUEZ-POSE A. (2011), Economists as geographers and geographers as something else: on the changing conception of distance in geography and economics, Journal of Economic Geography 11 (2), 347-356.

SANDBERG K. (2004), Growth of GDP in Chinese Provinces: A Test for Spatial Spillovers, ERSA Conference Paper, 1-24.

SETHAPRAMOTE Y. (2015), Synchronization of business cycles and economic policy linkages in ASEAN, Journal of Asian Economics 39, 126-136.

SHUMAN M. (1998), Going Local Creating Self-Reliant Communities in a Global Age, Free Press, New York.

STORONYANSKA I. Z. (2009), Inter-regional integration processes in Ukraine: trends and prospects, Institute if regional science NAS of Ukraine, Lviv.

STROTEBECK F. (2010), The Location Quotient - Assembly and application of methodological enhancements, MPRA Paper No. 47988, 1-15.

TURGANBAYEV Y. (2016), Regional convergence in Kazakhstan, Post-Communist Economies 28 (3), 314-334. 
VYKLYUK Y. I., YEVDOKYMENKO V. K., YASKAL I. V. (2016), The proportions and rates of economic activities as a factor of gross value added maximization in transition economy, Scientific Annals of Economics and Business 63 (1), 47-64.

XU X. (2002), Have the Chinese provinces become integrated under reform?, China Economic Review 13 (2-3), 116-133.

XU X., VOON J. P. (2003), Regional integration in China: a statistical model, Economics Letters 79 (1), 35-42.

YASKAL I. V. (2013), Internal Integration of the Transition Economy: Evidence from Ukraine, Global Journal of Human Social Science. Economics 13 (4), 37-43.

YEVDOKYMENKO V. K., YASKAL I. V. (2012), Interregional integration in Ukraine, Papers of conference "Dialogue between peoples and culture. East European cross border actors in the dialogue", 191-206.

YING L. G. (2003), Understanding China's Recent Growth Experience: A Spatial Econometric Perspective, The Annals of Regional Science 37 (4), 613-628.

ZUIDDAM V. S. (2016), Measuring Germany's economic integration: a statistical approach, Erasmus University Rotterdam, Rotterdam.

Initial submission: 12.10 .2017

Revised submission: 01.03 .2018

Final acceptance: 05.11.2018

Correspondence: Yuriy Fedkovych Chernivtsi National University, 2 Kotsjubynskyi Str., 58012 , Chernivtsi, Ukraine.

Email: igoryaskal@gmail.com 
